\title{
Energy and economic performance of novel integrated gasifier fuel cell (IGFC) cycles with carbon capture
}

\author{
A. Lanzini ${ }^{\text {a }, *}$, T.G. Kreutz ${ }^{\text {b }}$, E. Martelli ${ }^{c}$, M. Santarelli a \\ a Department of Energy, Politecnico di Torino, Corso Duca degli Abruzzi 24, 10129 Torino (IT), Italy \\ b Princeton Environmental Institute, Princeton University, Princeton, NJ 08544, USA \\ ${ }^{\mathrm{c}}$ Department of Energy, Politecnico di Milano, Milano 20156, Italy
}

\section{Introduction}

$\mathrm{CO}_{2}$ capture from large emitters such as power plants is an important task to be accomplished over the next few decades in order to curb greenhouse gas emissions in the electricity sector (IEA, 2012). In light of this goal, novel energy systems that promise high efficiency and low carbon emissions, such as fuel cell hybrid cycles with CCS (Discepoli et al., 2012; Campanari et al., 2010), merit research, development and detailed analysis of their prospec-tive economics. Of particular interest are SOFC-based power cycles, which have the potential to significantly increase the fuel-to-electricity conversion efficiency of next generation power plants. Moreover, capturing $\mathrm{CO}_{2}$ from SOFC-based power exacts a notably smaller efficiency penalty than that associated with conventional power cycles + CCS.

More than a decade ago, Singhal (1999) and Hassmann (2001) found that NG-fueled Siemens-Westinghouse hybrid gas turbinefuel cell cycles (at scales $>2-3 \mathrm{MW}$ ) without $\mathrm{CO}_{2}$ capture could achieve ideal conversion efficiencies as high as 70\% LHV; the system

\footnotetext{
* Corresponding author. Tel.: +39 0110904422.

E-mail addresses: andrea.lanzini@polito.it, lanzini.andrea@gmail.com (A. Lanzini).
}

investigated by Hassmann (2001) employed a 'sophisticated' turbine cycle (rather than, e.g., a micro-turbine). More recently, a 2011 DOE-NETL report (DOE/NETL, 2011a) on NG SOFC plants with $\mathrm{CO}_{2}$ capture calculated a LHV efficiency of $70.3 \%$ for a pressurized plant with external reforming of methane. According to a NETL review of conventional fossil energy power plants (DOE/NETL, 2010), the LHV efficiency penalty due to CCS is almost 8 percentage points (p.p.) in NG-fed combined cycles and $\sim 8-11$ p.p. for IGCC plants (depending on the specific gasifier employed). For NG pressurized hybrid SOFC cycles, Franzoni et al. (2008) calculated a CCS efficiency penalty of $<3$ p.p. using post-SOFC $\mathrm{CO}_{2}$ capture. Similarly, Park et al.(2011) calculated a LHV efficiency of $67.4 \%$ for a NG hybrid SOFC plant venting $\mathrm{CO}_{2}$, and $65.0 \%$ when $\mathrm{CO}_{2}$ was captured after the SOFC. In post-SOFC capture, the anode exhaust is oxy-combusted, yielding a stream containing mostly steam and $\mathrm{CO}_{2}$, from which the latter is separated after steam condensation and water knock-out.

Regarding coal IGFC plants, Grol (2009) investigated a pressurized SOFC integrated with a low temperature catalytic gasifier (producing a syngas with a relatively high methane content, $\sim 18 \%$ ), with/without post-SOFC CCS; LHV efficiencies of $62.4 \%$ and $59.2 \%$ were obtained in the vented and CCS cases, respectively. In another recent report, DOE-NETL (DOE/NETL, 2011b) calculated a LHV efficiency of $51.6 \%$ for a pressurized IGFC-CCS plant that employs an 


$\begin{array}{ll}\text { Nomenclature } \\ \text { AGR } & \text { acid gas removal } \\ \text { ASU } & \text { air separation unit } \\ \text { ASR } & \text { area specific resistance } \\ \text { BOP } & \text { balance-of-plant } \\ \text { COE } & \text { cost of electricity } \\ \text { CCS } & \text { CO }{ }_{2} \text { capture and storage } \\ \text { DOE } & \text { (US) Department of Energy } \\ \text { FU } & \text { fuel utilization } \\ \text { GT } & \text { gas turbine } \\ \text { HICOM } & \text { high CO methanation } \\ \text { HHV } & \text { higher heating value } \\ \text { HRSC } & \text { heat recovery steam cycle } \\ \text { HRSG } & \text { heat recovery steam generator } \\ \text { HX } & \text { heat exchanger } \\ \text { IGCC } & \text { integrated gasifier combined cycle } \\ \text { IGFC } & \text { integrated gasifier fuel cell } \\ \text { IRR } & \text { internal rate of return } \\ \text { LCOE } & \text { levelized-cost-of-electricity } \\ \text { LHV } & \text { lower heating value } \\ \text { MDEA } & \text { methyldiethanolamine } \\ \text { NETL } & \text { National Energy Technology Laboratory } \\ \text { PC } & \text { pulverized coal (power plant) } \\ \text { O\&M } & \text { operation and maintenance } \\ \text { SECA } & \text { Solid State Energy Conversion Alliance } \\ \text { SNG } & \text { substitute natural gas } \\ \text { SOFC } & \text { solid oxide fuel cell } \\ \text { TIT } & \text { turbine inlet temperature } \\ \text { TPI } & \text { total plant investment } \\ \text { TPC } & \text { total plant cost } \\ \text { TREMP } & \text { Topsoe's recycle methanation process } \\ \text { WGS } & \text { water gas shift } \\ \lambda & \text { (global) cathode air excess ratio } \\ & \end{array}$

enhanced gasifier able to produce a syngas with up to 11 vol.\% of methane.

Spallina et al. (2011a) designed and analyzed several IGFC plant configurations, all based on a Shell gasifier and a pressurized SOFC, with different gas turbine inlet temperatures (TITs); LHV efficiencies were 52-54\%. Spallina et al. (2011b) extended this work by adding post-SOFC $\mathrm{CO}_{2}$ capture via oxy-combustion of the anode exhaust, and calculated a 6\% drop in efficiency. Romano et al. (2011) studied a novel IGFC plant configuration that captures $\mathrm{CO}_{2}$ before the SOFC through physical absorption in a Selexol-based AGR unit; the plant design also features a methanation process upstream of the SOFC (to increase the methane content of the syngas to

$\sim 26$ vol.\%), a complete recycle of the shifted anode exhaust to the AGR unit for $\mathrm{CO}_{2}$ capture, and a state-of-the-art cooled gas turbine capable of exploiting both anode and cathode hot exhaust gases with high efficiency. With this configuration, a LHV efficiency of $51.7 \%$ was achieved, 4.5 percentage points higher than that of the plant proposed in Spallina et al. (2011b).

Rao (1991) was the first to propose the use of a methanator to convert part of the chemical energy of the synthesis gas into heat, and then to recover power from it efficiently through an expander. More recently, Li et al. (2010) investigated the role of a methanator and syngas expander topping cycle placed upstream an IGFC plant featuring a low-temperature catalytic gasifier (as employed in Grol (2009)); however, no significant improvement in efficiency was observed (with respect to the case without methanation) because the methane content of the syngas coming from the catalytic hydro-gasifier was already so high (36 vol.\%) to obscure the potential benefit of methanation upstream of the SOFC.
Note that this work significantly extends our preliminary findings, first presented at ASME Turbo Expo 2012 (Lanzini et al., 2012), on syngas methanation upstream of an SOFC power island. These new results represent a complete reanalysis of all cases, yield-ing a more complete description and a coherent interpretation of the effects of methanation. This paper is meant to entirely replace Lanzini et al. (2012), whose analysis is incomplete and, in parts, misleading.

\subsection{Motivation and scope}

This work evaluates the feasibility and impact of employing syngas methanation upstream of the SOFC in an IGFC based on com-mercial, high temperature, $\mathrm{O}_{2}$-blown, pressurized, entrained flow coal gasification. Three IGFC plant configurations, all with $\mathrm{CO}_{2}$ cap-ture, were designed and optimized in this study. In the reference case (DIRECT), sweet syngas is fed directly to the SOFC, while in the other two cases, the syngas is first partially methanated using com-mercially available processes: TREMP (Twigg, 1996) and HICOM (Udengaard et al., 2006).

In SOFC stacks with direct internal reforming (Massardo and Lubelli, 2000), which has now become a well-established option for planar Ni-based anode-supported stacks (Foger, 2010; Bose et al., 2007), the presence of methane in the fuel gas provides an effec-tive means for absorbing a significant portion of the waste heat produced by irreversibilities and the exothermic electrooxidation of fuel species. The endothermic reforming process converts SOFC waste heat directly into chemical energy, reducing the cooling duty and thus lowering the substantial auxiliary power required to compress cathode air for SOCF cooling. (Note that cathode air flow is the primary means of removing waste heat generated within the stack from the heat of reaction and overvoltage irreversibilities.) Because excess cathode air flow is a fairly inefficient method of heat removal, air-cooled SOFCs are significantly more efficient when operating on $\mathrm{NG}$ or $\mathrm{CH}_{4}$-rich biogas (due to their endother-mic reforming reactions) rather than $\mathrm{H}_{2}$ or (almost) methane-free syngas. Thus, in the atmospheric SOFCs, methane-rich fuels are generally preferred.

The highly exothermic methanation process also provides a convenient method of high temperature fuel gas preheating, poten-tially obviating costly heat exchangers and increasing the efficiency of expanding the pressurized syngas in a turbine prior to feeding it to an SOFC operating at a lower pressure. Thus, while it may seem counterproductive to methanate the syngas upstream of the SOFC only to immediately reform the methane within the SOFC, the potential advantages would appear to be significant. This analysis seeks to quantify the thermodynamic and economic ramifications of various "upstream methanation" strategies.

\subsection{Methodology}

Aspen Plus chemical process design software is used to calculate the performance of (and mass and energy balances around) all plant components. SOFC performance is simulated separately using a lumped volume, 0 -D model, and the cathode air requirement is determined by the energy balance of the SOFC 'hot-box' (Lanzini and Leone, 2010; Lanzini et al., 2010). An integrated waste heat recovery steam cycle is designed and rigorously optimized for each case using the novel method of Martelli et al. (2011a).

\section{Plant configurations and simulation models}

In this section we describe the arrangement of the three analyzed plant configurations, and the features of the main process units, namely the gasification process, the acid gas removal (AGR) 

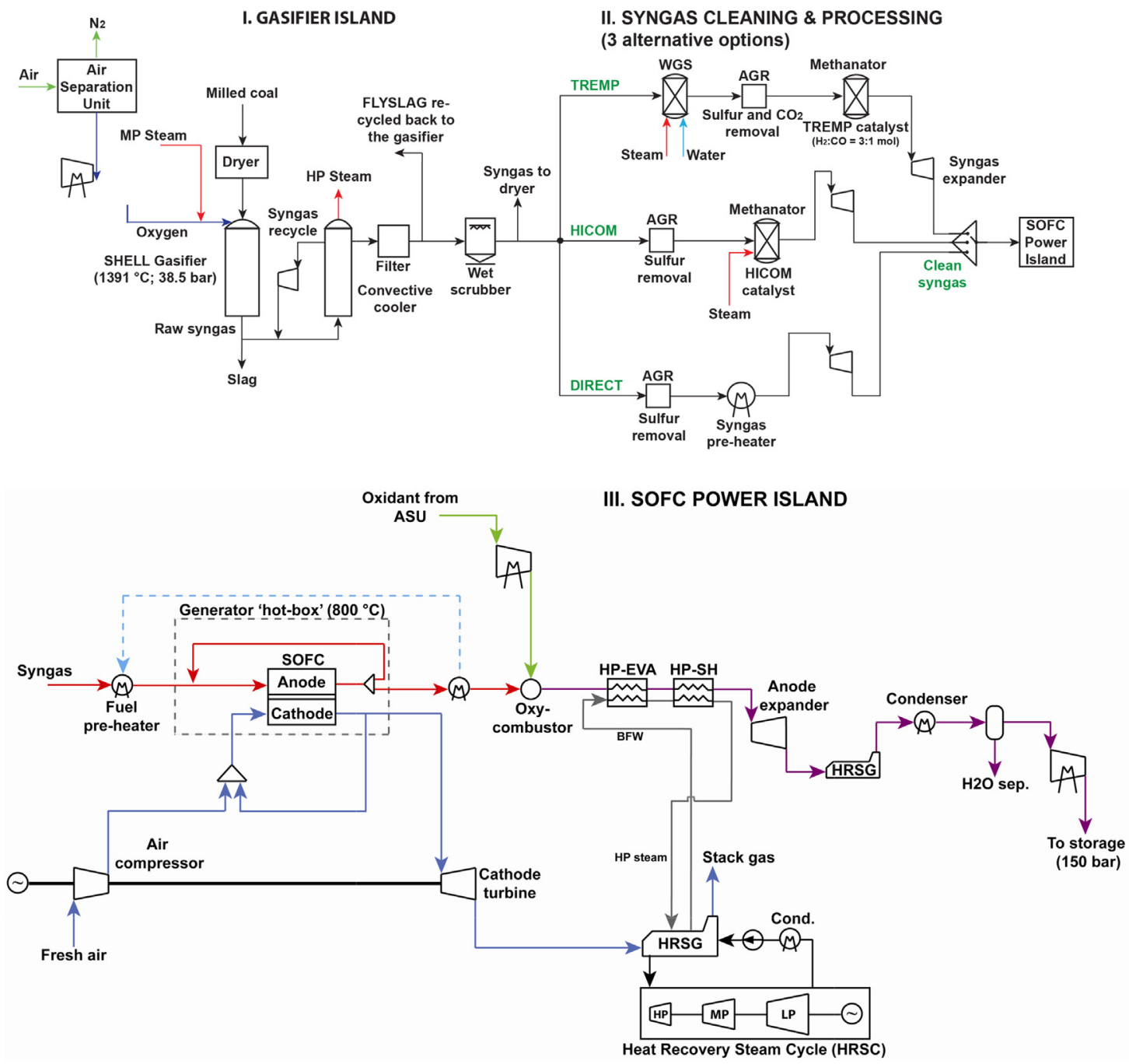

Fig. 1. Schematic of the three IGFC plants.

unit and the power island. A brief description of the SOFC simulation model is also provided.

\subsection{Plant configurations}

The three IGFC plants studied here employ a commercial, pressurized, $\mathrm{O}_{2}$-blown, entrained flow, dry-feed Shell coal gasifier whose syngas, after processing, feeds an $800^{\circ} \mathrm{C}$ pressurized SOFC. Post-SOFC $\mathrm{CO}_{2}$ capture is achieved by combusting the anode exhaust in oxygen to create a hot, pressurized mixture of $\mathrm{CO}_{2}$ and $\mathrm{H}_{2} \mathrm{O}$, which is expanded and cooled so as to condense out the water. The remaining (93 vol.\% pure) $\mathrm{CO}_{2}$ is compressed and dried in preparation for pipeline transport, and geologic storage. The electric power required to compress $\mathrm{CO}_{2}$ to 150 bar is included in the performance calculations for all cases. An uncooled gas turbine is used to both compress and heat air to feed the SOFC cathode, and to expand the hot cathode exhaust. Key modeling assumptions are summarized in Appendix (Table A.1). Fig. 1 illustrates the three alternative gas cleaning/pre-processing routes as well as the gasifier and power islands that are common to all three cases.

The DIRECT case represents the baseline IGFC plant, with a Shell gasifier and SOFC-based hybrid power cycle. Scrubbed syngas exiting the gasification island enters the AGR unit to remove sulfur compounds. The "sweet" syngas exiting the AGR is fed directly to the SOFC power island. In case DIRECT, no syngas methanation occurs before the SOFC plant.

The 'TREMP' case employs a single Haldor Topsoe TREMP ${ }^{\circledR}$ methanation reactor upstream of the SOFC to increase the methane content of the feed gas. The S-containing syngas exiting the scrubber undergoes a "sour" (Co-Mo-based) partial water-gas shift (WGS) to produce syngas with a $\mathrm{H}_{2} / \mathrm{CO}$ molar ratio of 3.0 in preparation for methanation. The advanced WGS unit uses a staged design to reduce steam consumption (DOE/NETL, 2011a; Carbo et al., 2009a,b). A fraction of the entering syngas is combined with steam (to achieve a $\mathrm{H}_{2} \mathrm{O} / \mathrm{CO}$ mole ratio of 2.1 and thus avoid catalyst coking), heated to $250{ }^{\circ} \mathrm{C}$ and reacted in the first catalytic WGS reactor. The remaining syngas bypasses the reactor and is combined with its effluent and feed water (again so that $\mathrm{H}_{2} \mathrm{O} / \mathrm{CO}=2.1$ and $T=250{ }^{\circ} \mathrm{C}$ ) before entering the final WGS reactor. The exiting shifted syngas then enters a Rectisol-based absorption process to capture both $\mathrm{CO}_{2}$ and $\mathrm{H}_{2} \mathrm{~S}$. The WGS and AGR units serve to provide a syngas whose composition is well suited to the TREMP methanation reactor which yields syngas with a high methane content ( $\sim 37$ vol.\%, on a dry basis), where almost all the $C$ in the inlet syngas has been converted to $\mathrm{CH}_{4}$.

As with TREMP configuration, case HICOM (HIgh CO Methanation) also employs a methanation unit upstream of the SOFC generator to increase the $\mathrm{CH}_{4}$ content of the SOFC feed. The HICOM catalyst is Ni-based (Twigg, 1996; Udengaard et al., 2006; Penner, 
Table 1

Performance results of the IGFC configurations in this study.

\begin{tabular}{|c|c|c|c|}
\hline Plant type & DIRECT & TREMP & HICOM \\
\hline \multicolumn{4}{|l|}{ Fuel input } \\
\hline Coal input (LHV), $\mathrm{MW}_{\mathrm{th}}$ & & 1828 & \\
\hline Clean syngas fed to SOFC, $\mathrm{kmol} / \mathrm{s}$ & 6.06 & 3.38 & 8.26 \\
\hline $\mathrm{CH}_{4}$ concentration in syngas fed to SOFC, $\mathrm{mol} \%$ & $2.8 \%$ & $37.0 \%$ & $11.5 \%$ \\
\hline \multicolumn{4}{|l|}{ SOFC power unit } \\
\hline Global fuel utilization $(F U)$ & & $85 \%$ & \\
\hline Global air utilization $(\lambda)$ & 3.95 & 1.59 & 2.15 \\
\hline Operating voltage, $\mathrm{V}$ & 0.781 & 0.788 & 0.769 \\
\hline \multicolumn{4}{|l|}{ Power production, $A C M W_{e}$} \\
\hline Syngas expander & 15.4 & 7.2 & 19.1 \\
\hline SOFC power, AC (Inverter efficiency: 96\%) & 702.8 & 706.1 & 693.1 \\
\hline GT net power $\left(\mathrm{TIT}=800^{\circ} \mathrm{C}\right)$ : & 130.1 & 27.3 & 52.0 \\
\hline Cathode exhaust expander & 742.5 & 272.0 & 385.7 \\
\hline Cathode air compressor & 610.0 & 244.2 & 332.7 \\
\hline Anode expander $\left(\mathrm{TIT}=850^{\circ} \mathrm{C}\right)$ & 122.3 & 109.5 & 191.0 \\
\hline HRSC net power from steam expansion & 184.3 & 263.3 & 214.0 \\
\hline \multicolumn{4}{|l|}{ Auxiliary power consumption, $A C M W_{e}$} \\
\hline Coal prep. \& handling + slag handling & 4.6 & 4.6 & 4.6 \\
\hline Oxidant to the gasifier (ASU) & 63.8 & 63.8 & 63.8 \\
\hline Syngas recycle compressor & 0.1 & 0.1 & 0.1 \\
\hline $\mathrm{AGR}^{\mathrm{a}}$ & 10.1 & 54.5 & 10.1 \\
\hline Methanator recirculator & 0.0 & 1.1 & 0.5 \\
\hline $\mathrm{O}_{2}$ compressor & 5.4 & 5.3 & 5.3 \\
\hline Oxidant to the oxy-combustor (ASU) & 13.4 & 13.1 & 13.3 \\
\hline $\mathrm{CO}_{2}$ compression $\left(\mathrm{CO}_{2}\right.$ removed pre-SOFC) & n.a. & 33.0 & n.a. \\
\hline $\mathrm{CO}_{2}$ compression $\left(\mathrm{CO}_{2}\right.$ removed post-SOFC $)$ & 73.7 & 33.3 & 73.7 \\
\hline Net power output, $A C M W_{e}$ & 983.9 & 904.6 & 997.9 \\
\hline AC electrical efficiency, $\eta_{\mathrm{AC}}$ (HHV coal) & $51.4 \%$ & $47.2 \%$ & $52.1 \%$ \\
\hline AC electrical efficiency, $\eta_{\mathrm{AC}}$ (LHV coal) & $53.8 \%$ & $49.5 \%$ & $54.6 \%$ \\
\hline $\mathrm{CO}_{2}$ captured pre-SOFC, $\mathrm{kg} / \mathrm{s}$ & n.a. & 98.6 & n.a. \\
\hline $\mathrm{CO}_{2}$ captured post-SOFC, $\mathrm{kg} / \mathrm{s}$ & 162.3 & 63.7 & 162.2 \\
\hline
\end{tabular}

a $\mathrm{H}_{2} \mathrm{~S}$ removal only for DIRECT' and HICOM cases, $\mathrm{H}_{2} \mathrm{~S}+\mathrm{CO}_{2}$ co-removal in TREMP case.

1987) (as is the TREMP catalyst), but can withstand syngas with a high CO content provided that a sufficient amount of steam is cofed to the reactor to avoid coking. The amount of steam is determined by calculating full chemical equilibrium at the temperature and pressure at the methanation reactor inlet, using the thermodynamic properties of graphite as a model for those of coke. As seen below (Table 1 ), in the HICOM case, $\sim 40 \%$ less methane is produced than in the TREMP case, and although the required cathode air flow is greatly reduced (compared to the DIRECT case), it is not at its lower limit. A multi-stage methanator might achieve this result, although its economic viability is less clear; this option was not investigated further here.

\subsection{Main process units}

\subsubsection{Gasifier island}

The design and main operating parameters of the gasification island were calibrated in order to simulate the Shell coal gasification process with gas quench and syngas coolers, as detailed in (IEA, 2003). Illinois \#6 bituminous coal (DOE/NETL, 2010) coal is milled, dried to a moisture level of $2 \mathrm{wt} . \%$, and fed into the gasifier via lock-hopper pressurization using $\mathrm{N}_{2}$ as a transport gas. The coal is gasified in the presence of medium pressure (MP) steam and $95 \%$ oxygen from a stand-alone cryogenic air separation unit (ASU). Gasification is modeled using full chemical equilibrium at 38.5 bar and $1390{ }^{\circ} \mathrm{C}$. Steam and oxidant flows are set by maximizing the LHV of the raw synthesis gas exiting the gasifier while maintaining a fixed fraction of the throughput power extracted by the membrane wall surrounding the gasifier. Much of the input mineral matter exits the bottom of the gasifier as a vitreous slag; the remainder is captured as fly ash (after syngas cooling) by a ceramic filter and recycled back to the coal milling/ drying unit.

The hot $\left(1390{ }^{\circ} \mathrm{C}\right)$ raw syngas leaving the gasifier is first quenched to $900{ }^{\circ} \mathrm{C}$ by mixing with $250{ }^{\circ} \mathrm{C}$ recycled syngas; the syngas temperature is further reduced to $250{ }^{\circ} \mathrm{C}$ in syngas cool-ers that generate high pressure saturated steam. The cooled syngas is then filtered with the ceramic filter. Recycling the fly ash captured by the ceramic filter boosts the overall carbon conversion of the gasification process to $99.8 \%$. The cooled, filtered syngas is scrubbed with hot water to remove fugitive particulates and water-soluble impurities. A more detailed description of the gasifier model is given in Martelli et al. (2011b).

\subsubsection{Rectisol process}

All three plant configurations employ a Rectisol AGR unit to remove sulfur compounds (mainly $\mathrm{H}_{2} \mathrm{~S}$ and $\mathrm{COS}$ ) down to the stringent limits required by the Ni-based methanation catalysts $(<0.1 \mathrm{ppmv}$ (Twigg, 1996)) and SOFC anode electrode $(<0.1 \mathrm{ppmv}$ (Israelson, 2004)). For the DIRECT and HICOM plants, a conventional Rectisol process for $\mathrm{H}_{2} \mathrm{~S}$ removal (single absorber column plus single stripping column with reboiler) was simulated in Aspen Plus following data reported in Kohl and Nielsen (1997). The TREMP plant requires an AGR design that also removes $\mathrm{CO}_{2}$ in order to boost the methanation conversion efficiency and reduce the reactor size. For this reason, the "selective" Rectisol process was selected and modeled in Aspen Plus following data in the original patent by Linde. Further details on the Rectisol model are given in Martelli (2010). Note that both the AGR processes require low temperature steam for the stripper reboiler.

\subsubsection{Methanation processes}

In the TREMP and HICOM cases, the syngas feeding the SOFC was partially methanated in the methanation unit shown in Fig. 2. The input syngas is mixed with a cooled recycle stream to create a dilute feed stream at $250{ }^{\circ} \mathrm{C}$ that enters an adiabatic catalytic methanation reactor (calculated assuming full chemical equilibrium). The recycle fraction is set so that the reactor exit temperature is $700{ }^{\circ} \mathrm{C}$, 


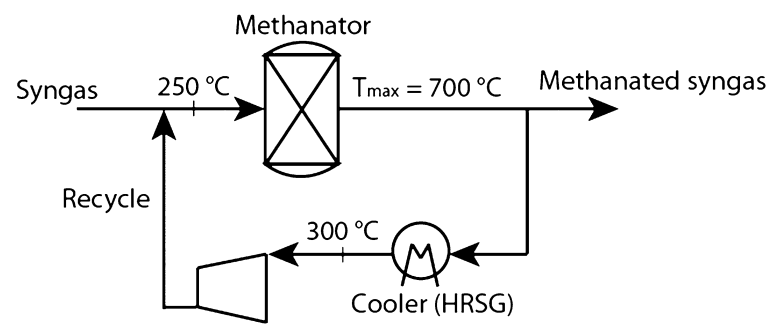

Fig. 2. Methanation unit for the TREMP and HICOM cases.

above which catalyst sintering can occur (Rostrup-Nielsen et al., 2007; Pedersen et al., 1980).

Our use of only one methanation reactor limits somewhat the production of methane. In SNG plants using the full HICOM and TREMP processes, more elaborate configurations (with sev-eral reactors, inter-stage coolers and recycle loops) are generally employed to maximize methane conversion. However, a single reactor with recycle (which significantly increases the methane content of the syngas) is consonant with our goal of identifying cost-effective ways to improve SOFC performance when coupled to commercial, high temperature, entrained flow gasifiers. As discussed below, the methane conversion is almost complete in the TREMP case, but somewhat less so in the HICOM configuration, where a second reactor might yield further benefits.

\subsubsection{SOFC power island}

The SOFC power island (Fig. 1) is common to all three cases. As described below and in Spallina et al. (2011a), the SOFC sys-tem assumed here is a network of parallel megawatt-scale modules connected to main pipelines that separately bring air from the GT compressor and fuel from the gasification island, while returning separate cathode and anode exhaust streams to the GT cathode expander and the oxy-combustor, respectively. Each module consists of a pressurized vessel containing several SOFC stacks, internal recirculators and heat-exchangers for pre-heating the feed streams and cooling the exhaust flows.

The modules are based on planar-type SOFC stacks, featuring $\mathrm{Ni}$-based anode-supported fuel cells (e.g., those developed by TOPSOE Fuel Cells and Ceramic Fuel Cells Ltd.). The modules are pressurized to $\sim 20$ bar on both sides (anode and cathode) to match the oper-ating pressure of the industrial-scale turbomachinery employed here. Since the gasifier operates at 38 bar, the syngas pres-sure is reduced by expanding the syngas upstream of the SOFC. ${ }^{1}$ Both the anode and cathode exhausts are partially recirculated using hot gas recirculators (Agrawal, 2009) which compensate for pressure drops in each recycle loop respectively. Their electric con-sumption is almost negligible due to the very low pressure drop ( $<50-100$ mbar) through SOFC stacks and surrounding inlet/outlet manifolds. A possible and proven alternative to hot recirculators is the use of ejectors. They result in reduced plant complexity as do not involve mechanical moving parts (Lanzini et al., 2010). Drawbacks of an ejector-based recirculation system are that it can-not be actively regulated during the off-design of the SOFC and that an over-pressure of the primary stream (e.g., fresh air stream for cathodic recirculation) is needed to produce the entraining effect, that accounts for additional parasitic consumption of fuel/air compressor (Liu et al., 2013).

\footnotetext{
${ }^{1}$ Level for each case was not attempted here. As shown in Lanzini (2011), the Nernst voltage increases sharply with pressures up to 5-7 bar; further pressurization is not necessarily beneficial (only a slight increase in plant efficiency is observed above 10 bar).
}

In the analyzed plants, anode recirculation is employed to provide a (molar) steam-to-carbon ratio of 2 at the SOFC anode, that prevents the risk of carbon formation on the Ni electrocatalyst present. Cathode recirculation is used instead to pre-heat cold inlet air. Fresh air is pre-heated at $650{ }^{\circ} \mathrm{C}$ by mixing with the $\mathrm{O}_{2}$-depleted air exhaust from the SOFC. The recirculation fraction is chosen to avoid oxygen starvation in the cathode, where the oxygen partial should never reach values below $10 \mathrm{~mol} \%$.

The air compressor provides pressurized air to the inlet of the SOFC cathode, and the cathode exhaust is expanded in an uncooled turbine. The anode exhaust is oxy-combusted, cooled to $850^{\circ} \mathrm{C}$ (by evaporating and superheating high pressure steam) before being expanded to nearly atmospheric pressure in an uncooled turbine to generate additional power. Expansion lowers the temperature of the oxy-combusted anode exhaust prior to final cooling and condensation to separate $\mathrm{CO}_{2}$ from $\mathrm{H}_{2} \mathrm{O}$.

2.2.4.1. SOFC pressurization. In this study of large scale power production, the SOFC modules are operated at relatively high pressures in order to reap the thermodynamic benefits of close integration with large gas turbines. From a practical standpoint, pressurized operation might also be required in order to reduce the consider-able footprint of a $\mathrm{GW}_{\mathrm{e}}$-scale SOFC power island (Lanzini, 2011).

Operating planar SOFCs at the relatively high pressures $(\sim 20$ bar) assumed here is deemed to be feasible as long as the thin ceramic electrolyte membranes are not exposed to significant pressure differentials (Traverso et al., 2010). SOFC manufactur-ers (e.g., Rolls-Royce Fuel Cell Division (Trasino et al., 2011) and DLR, the German Aerospace Center DLR (Seidler et al., 2011)) are currently operating single cells and planar stacks at pressures of 37 bar. When operating a pressurized SOFC/GT hybrid (i.e., with a gas turbine providing both cathode pressurization as well as power recovery from the hot cathode exhaust), transient fluctuations in pressure are perhaps the most critical concern, as even modest pressure differences between the anode and cathode chambers can damage or entirely destroy the fuel cell. Higher SOFC oper-ating pressures require more accurate and costly control systems, and are likely to engender higher O\&M costs and reduced system availability. Furthermore, as a result of elevated partial pressures of the reactant and product gases, high pressure operation may also accelerate common chemical reaction-based SOFC degrada-tion mechanisms, such as interconnector oxidation and electrode phase instability.

Such considerations require careful investigation before high pressure SOFC/GT operation can be considered a realistic option. In this study, we simply assume that such operation is feasible, and incurs no additional cost or operational penalties.

2.2.4.2. SOFC model. A simplified lumped model for the SOFC stack is used for energy system analysis calculations in this work. Spa-tially resolved stack models are clearly more accurate to predict thermal gradients and electrochemical performances (McLarty et al., 2013), however they are intrinsically dependent on geom-etry and cell typology, a level of detail that is beyond the scope of this study.

The SOFC, operated at $800^{\circ} \mathrm{C}$, has an operating voltage, $V_{\text {cell }}$, given by:

$V_{\text {cell }}=V_{G}(T, p, y)-j \cdot$ ASR,

where $T, p$ and $y$ denote respectively the average SOFC stack temperature and pressure and the molar basis composition of the syngas; $V_{G}$ denotes the average Gibbs (or reversible) potential that would be generated by the electrochemical oxidation of $\mathrm{H}_{2}, \mathrm{CO}$ and $\mathrm{CH}_{4}$ (which depends on $T, p$ and $y$ ), ASR denotes the cell's area specific resistance and $j$ denotes the average stack operating current density. By assuming the stack to operate in reversible mode 
(i.e., without polarization losses), the voltage generated under this condition is called the 'Gibbs voltage', defined as:

$V_{G}=\frac{-\Delta G^{r}(T, p)}{I_{\text {farad }}}=\frac{-\sum_{i} \pm n_{i} \cdot g_{i}}{n_{a n, i n} \cdot n^{e l} \cdot F \cdot F U}$,

where $n_{i}$ is the molar flow rate of each stream either entering or exiting the control volume surrounding the SOFC stack (the sign ' + ' denoting a stream entering the stack - both the anode and cathode inlet feeds - the sign '-' otherwise, that is the case of the anode and cathode exhausts streams) and $g_{i}$ is the specific (molar) Gibbs free energy associated with the $i$ th stream. In the denominator of Eq. (2), $I_{\text {farad }}$ is the total (faradic) current generated in the fuel cell stack and is defined by the total molar flow of the anode inlet mixture, $n_{a n, i n}$, the mixture-weighted number of electrons, $n^{e l}$, that are available for the electrochemical oxidation of fuel compounds (e.g., $\mathrm{H}_{2}, \mathrm{CO}$ and $\mathrm{CH}_{4}$ ) contained in the anode mixture, the Faraday constant, $F$, and the fuel utilization factor, $F U$.

In this work we make the following assumptions about the cell operating parameters:

- ASR $=0.28 \Omega \mathrm{cm}^{2}$ (Milewski et al., 2011); this value, designed to simulate the performance of a planar SOFC operating at high pressure, is derived from a baseline value of $0.38 \Omega \mathrm{cm}^{2}$ (from data reported by manufacturers in the SECA program for a generic, state-of-the-art planar SOFC operating at atmospheric pressure) that is reduced by $25 \%$ to account for enhanced polarization at 20 bar.

- The average operating current density, $j$, is $0.64 \mathrm{~A} / \mathrm{cm}^{2}$. In order to avoid excessive degradation rates ( $>1 \%$ per $1000 \mathrm{~h}$ ), today's planar stacks generally operate at current densities of $0.25-0.30$ $\mathrm{A} / \mathrm{cm}^{2}$, yielding a power density of $\sim 250 \mathrm{~mW} / \mathrm{cm}^{2}$. A power density of $500 \mathrm{~mW} / \mathrm{cm}^{2}$ (used in all SOFC calculations presented here) is a target value representing stack operation at enhanced current densities, prospectively made possible by improved cell resis-tance to common modes of degradation, such as $\mathrm{Ni}$ coarsening, electrolyte micro-cracking, cathode delamination, etc.

- The global fuel utilization (FU) is 85\% (DOE/NETL, 2011a), thus assuring a water steam anode outlet molar fraction always below $60 \%$; higher values of FU - resulting in higher $p\left(\mathrm{H}_{2} \mathrm{O}\right)$ values at the anode side - could lead to accelerated anode microstructure degradation by Ni sintering. In the study of Thydén it is proposed that the mobility of $\mathrm{Ni}$ is facilitated by the formation of $\mathrm{Ni}-\mathrm{OH}$ complexes which are capable of segregating on the Ni particles surface, on the YSZ surface and via gas phase (Thyden, 2008).

Given these parameters, the resulting SOFC power density is $\sim 500 \mathrm{~mW} / \mathrm{cm}^{2}$ (which is also the reference value for the pressurized SOFC modeled in the NETL reports (DOE/NETL, 2011a,b) used for capital cost estimates).

Eqs. (1) and (2) represent a simple SOFC model that is able to incorporate the effects of fuel/oxidant composition by means of an accurate Nernst voltage calculation averaged between the SOFC inlet and outlet diffusion channels. In this way, concen-tration losses due to mixing between the fresh fuel and the exhaust are accounted for. The ASR is assumed here to be a constant that expresses the cell's overall equivalent resistance, including 'ohmic' + 'activation' + 'contact resistance' contributions. Ideally, the cell's (or stack's) ASR would be an experimental value provided by the fuel cell manufacturer, measured at thermody-namically and fluiddynamically relevant conditions (i.e., at the nominal SOFC temperature and high $F U$ ). In a real SOFC, the ASR varies with operating temperature due to the strong temperaturedependences of both ohmic and activation losses; it also depends weakly on current density. However from a practical stand-point of view, within a limited operating range (e.g., at relatively high $F U$ and current density), the ASR can be taken as a constant, yielding a simple linear dependence between the cell's polarization and the current density, as indicated in Eq. (1).

2.2.4.3. SOFC operating condition. In all the plant configurations considered here, the fuel cell is operated at 20 bar and $800{ }^{\circ} \mathrm{C}$. Partial anode exhaust recirculation ${ }^{2}$ is employed to provide an $\mathrm{O} / \mathrm{C}$ atomic ratio $\geq 2$ at the anode inlet to prevent coking on the Ni-based anode (note that the risk of carbon deposition is reduced essentially by recycling $\mathrm{H}_{2} \mathrm{O}$; an atomic $\mathrm{O} / \mathrm{C}$ of 2 yields exactly the same amount of steam that one would have by declaring a molar steam-to-carbon ratio of equal value). To minimize thermal stresses, the anode feed stream is pre-heated at $700{ }^{\circ} \mathrm{C}$ prior to entering the stack; note that the pre-heater duty is reduced by anode exhaust recirculation. In general, the necessary preheating temperature is governed by the methane content of the anode feed stream due to the strong endothermicity of methane steam reforming that occurs within the stack; as the methane content increases, so does the required preheating temperature. On the cathode side, partial exhaust recirculation is also employed to pre-heat the cathode feed stream to 650 ${ }^{\circ} \mathrm{C}$ before entering the stack. To avoid significant reductions in Nernst voltage due to oxygen starvation, a lower limit on the cathode air flow is imposed to insure that the molar fraction of $\mathrm{O}_{2}$ in the cathode exhaust exceeds 10 vol.\%.

\subsubsection{Heat recovery steam cycle (HRSC)}

In all cases, an optimized multiple pressure level + reheat steam cycle was employed to recover waste heat both from the anode and cathode turbine exhausts, as well as from the plant-wide network of heat exchangers, including those in the gasifier island and the fuel cleaning/processing section. Heat integration between hot and cold process streams was first optimized separately for each plant con-figuration using the standard techniques of pinch analysis (Linnhoff and Hindmarsh, 1983). The HRSC was then designed and optimized using the novel methodology of Martelli et al. (2011a) and Martelli (2010). Given a set of specified technoeconomic constraints typ-ically adopted by the industry, the HRSC optimizer identifies the particular heat-exchanger network and associated steam cycle that can most efficiently recover and convert waste heat into electricity. All the possible integrations are considered between the process heat sources/users and the two heat recovery steam generators (HRSGs) located at the outlets of cathode and anode turbines. The algorithm simultaneously optimizes the HRSC design and the steam cycle parameters (pressures and temperatures) to achieve the max-imum plant efficiency while taking into account the process steam users (i.e., units absorbing steam, like the water gas shift reactor and the AGR reboiler) and the techno-economic constraints. The primary constraints used in this study are summarized below:

- Superheaters and reheaters are not allowed in syngas coolers. Only downstream of the methanator is it possible to superheat (or reheat) steam if its pressure and temperature fall within the current technological limitations $\left(<120\right.$ bar, $\left.<520^{\circ} \mathrm{C}\right)$. The TREMP process is capable of superheating steam up to $520{ }^{\circ} \mathrm{C}-120 \mathrm{bar}$ without risk of "metal dusting 3 " (Haldor Topsoe).

- Pinch point temperature differences in the HRSGs $>8^{\circ} \mathrm{C}$.

\footnotetext{
2 When operating an SOFC with recirculation of the exhausts, it is convenient to express the consumption of the reactants (or conversely, their "excess ratio") in both global and local terms. The global FU refers to the FU experienced by the SOFC as a whole (i.e., using a control volume that includes the recirculation loop), while the local $F U$ refers to the $F U$ calculated using a control volume that excludes the recirculation loop.

${ }^{3}$ Metal dusting is a severe form of corrosion that attacks metals and alloys at high temperatures, within the range $350-850^{\circ} \mathrm{C}$, under high CO partial pressures and low sulfur concentrations.
} 
Table 2

HRSC design and performance.

\begin{tabular}{lccc}
\hline Plant design & DIRECT & TREMP & HICOM \\
\hline HRSC electrical efficiency & $25.7 \%$ & $40.3 \%$ & $37.9 \%$ \\
Number of pressure levels & 3 & 3 & 3 \\
Low pressure (LP) level, bar & 4.0 & 4.0 & 20.0 \\
Medium pressure (MP) level, bar & 32.3 & 35.4 & 90.0 \\
High pressure (HP) level, bar & 76.2 & 109.3 & 170.0 \\
Super-heating (SH) temperatures & & & \\
$\quad$ SH-LP, ${ }^{\circ} \mathrm{C}$ & 212 & 272.2 & 358.4 \\
SH-MP, ${ }^{\circ} \mathrm{C}$ & 495.8 & 598.2 & 600.0 \\
SH-HP, ${ }^{\circ} \mathrm{C}$ & 401.8 & 517.7 & 600.0 \\
Mass flow rates of steam generated & & & \\
LP steam, kg/s & 36.5 & 16.6 & 1.3 \\
MP steam, kg/s & 90.6 & 20.1 & 162.9 \\
HP steam, kg/s & 59.3 & 207.5 & 45.3 \\
\hline
\end{tabular}

Turbine steam extractions: (DIRECT) $5.4 \mathrm{~kg} / \mathrm{s}$ at 42 bar for the gasifier, $11.2 \mathrm{~kg} / \mathrm{s}$ at 0.7 bar for the Rectisol reboiler; (TREMP) $5.4 \mathrm{~kg} / \mathrm{s}$ at 42 bar for the gasifier, $36.6 \mathrm{~kg} / \mathrm{s}$ at 35 bar for the WGS unit, and $58.6 \mathrm{~kg} / \mathrm{s}$ at 2.3 bar for the Rectisol reboilers; (HICOM) $5.4 \mathrm{~kg} / \mathrm{s}$ at $42 \mathrm{bar}$ for the gasifier, $61.8 \mathrm{~kg} / \mathrm{s}$ at 31 bar for the methanation process, and $9.8 \mathrm{~kg} / \mathrm{s}$ at 0.7 bar for the Rectisol reboiler.

- Pinch point temperature differences between process streams and steam/water $>15^{\circ} \mathrm{C}$.

- High pressure levels < 170 bar; low pressure level $>4$ bar (to avoid oversized tubes and pipes).

- Superheat and reheat temperatures $<600^{\circ} \mathrm{C}$.

\subsubsection{Pressure losses}

Pressure losses are an important consideration, since cumulatively the many small pressure drops throughout a plant can significantly reduce its overall efficiency. An accurate accounting would require a detailed knowledge of the geometry of each plant component, information that is not readily available. Instead, we have estimated and assigned pressure drops to each component after carefully reviewing previous studies on systems whose operating pressures are similar to those used here (Park et al., 2011; Grol, 2009; Trasino et al., 2011; Adams and Barton, 2010). Particular attention must be given to the SOFC unit: on the basis of the data found in Park et al. (2011), Trasino et al. (2011) and Adams and Barton (2010), an overall pressure loss of 2 bar was assumed for both the air/cathode and the fuel/anode (open) loops.

\section{Plant performance results}

Table 1 contains key performance results for all three IGFC plants, which are scaled to the same coal input (1828 $\mathrm{MW}_{\text {th }} \mathrm{LHV}$ ) in order to facilitate comparisons between cases. The net electrical plant efficiency was calculated accounting for both power producing devices (SOFC, GT, anode expander and HRSC) and parasitic consumption by auxiliaries (coal and slag handling, ASU for oxygen production, AGR, syngas recycle compressor, methanator recirculator, $\mathrm{CO}_{2}$ compression train for CCS, etc.). A detailed list of these devices and related power production/consumption is given in Table 1. The chemical power input (coal input) to the plant on a LHV basis is also provided in the same table.

The main features of the optimized HRSCs are summarized in Table 2. In Fig. 3 the heat-temperature composite curves for the plants analyzed are also provided.

To understand the results, it is instructive to first compare the simpler of the two methanation configurations, HICOM, with the base case, DIRECT. By generating an extra $14 \mathrm{MW}_{\mathrm{e}}$ net power, which represents only a small fraction (1.2\%) of the gross power generated, HICOM is slightly more efficient than DIRECT (54.6\% vs. 53.8\% LHV). Since auxiliary power consumption is essentially the same for both cases, the difference between the two is lies solely in their power generation. Upstream of HICOM methanation, $67.7 \mathrm{~kg} / \mathrm{s}$ of $250{ }^{\circ} \mathrm{C}$ steam $\left(\sim 200 \mathrm{MW}_{\mathrm{th}}\right)$ is added to the sweet syngas, which not only
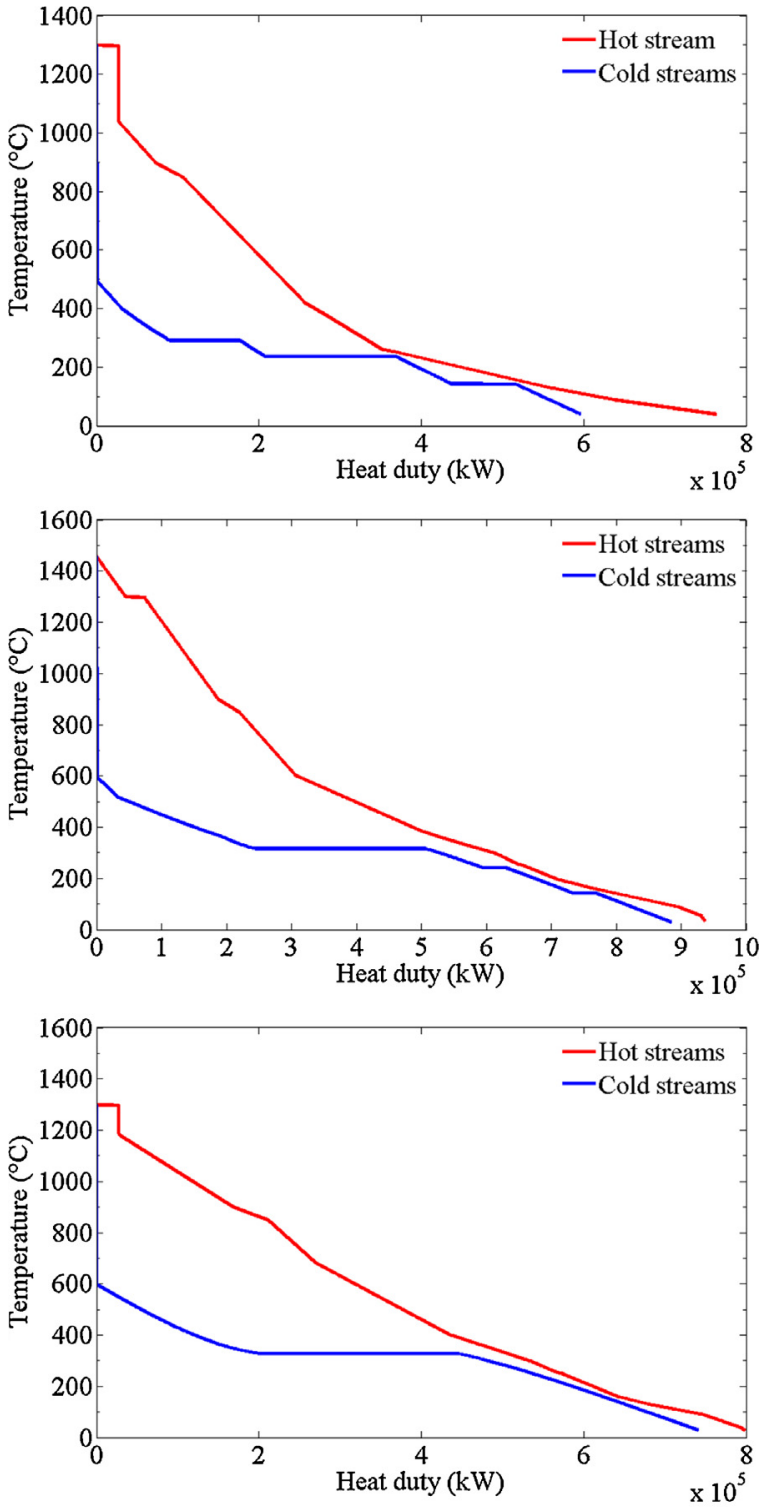

Fig. 3. Composite temperature-heat curves of the IGFC plants. (a: DIRECT; b: TREMP; c: $\mathrm{HICOM})$.

increases the flow rate of syngas $\mathrm{CH}_{4}$ by a factor of 5.6 , but also boosts the total mass flow of the syngas by $55 \%$. As seen in upper section of Table 1 , the increased methane concentration essentially halves the SOFC waste heat and air flow handled by the cathode GT.(The cathode air flow is found to be inversely proportional to the methane content in the SOFC fuel gas.) However, in contrast to a traditional atmospheric SOFC, where increased $\mathrm{CH}_{4}$ concentrations in the feeding fuel typically increase overall efficiency by reducing waste heat and the significant parasitic load associated with cathode air cooling (Lanzini and Leone, 2010), the effect of syngas methanation in pressurized SOFC-GT hybrids is much less straight-forward. In the configurations studied here, the SOFC serves as the "combustor" in the cathode air GT topping cycle that produces a significant amount of power $(>11 \%$ gross in DIRECT); a reduction in the amount of SOFC waste heat leads to an equal reduction in cathode GT power, e.g., HICOM's cathode GT generates only $40 \%$ of the power produced in DIRECT's GT. Furthermore, while we anticipated that syngas methanation would increase the DC SOFC power output (by converting SOFC waste heat into chemical enthalpy during internal reforming), Table 1 instead indicates a small loss (1.4\%) 
of SOFC power. This is because methanation and reforming essentially "cancel out" each other, and in addition, the Nernst potential falls slightly due to dilution of the syngas by steam.

Offsetting the power losses caused by HICOM methanation are: (1) a $56 \%$ increase in power output $\left(+68.7 \mathrm{MW}_{\mathrm{e}}\right)$ from the anode exhaust expander (mirroring the 55\% increase in anode mass flow rate) and (2) a 25\% increase in the syngas expander (+3.7 $\mathrm{MW}_{\mathrm{e}}$ ). However, these alone are insufficient to render HICOM methanation superior to the DIRECT configuration; summing all contributions discussed thus far, HICOM produces $15.5 \mathrm{MW}_{\mathrm{e}}$ less power than DIRECT.

Ultimately, the component that renders HICOM more efficient than DIRECT is the optimized HRSC, which produces $29.7 \mathrm{MW}_{\mathrm{e}}$ more power in HICOM than in DIRECT. The composite curves shown in Fig. 3 provides an overview of heat integration between the process heat exchangers (hot curve) and the HRSC (cold curve). From these temperature-heat diagrams, the overall amount of heat recovered is shown as well as the amount rejected to the environment. It is worth noting that the horizontal tracts of the cold curve correspond to the optimized pressure levels of the steam cycle (i.e., 3 pressure levels for the DIRECT and TREMP cases, and only one level for the HICOM).

It is worth noting that the HICOM design yields a bottoming cycle with a significantly higher first law efficiency than the DIRECT case (37.9\% vs. 25.7\%). Two reasons for this outcome stand out. First, the HICOM methanator, which converts $\sim 200 \mathrm{MW}_{\text {th }}$ of chem-ical enthalpy from the entering sweet syngas (1532 $\mathrm{MW}_{\text {th }}$ LHV), effectively "upgrades" $260 \mathrm{MW}_{\text {th }}$ of relatively low grade (250 $\left.{ }^{\circ} \mathrm{C}\right) \mathrm{MP}$ steam - $60 \mathrm{MW}_{\text {th }}$ used for syngas preheating and $200 \mathrm{MW}_{\text {th }}$ of injected steam - boosting the temperature of the latter to $680{ }^{\circ} \mathrm{C}$ (within the preheated SOFC feed gas). This enthalpy is eventually recovered relatively efficiently by raising high pressure steam after oxy-combustion and further heat recovery after the anode exhaust expander $\left(850^{\circ} \mathrm{C}\right.$ TIT $)$. Second, in the recycle cooler HICOM methanation further releases back to the bottoming cycle $\sim 90 \mathrm{MW}_{\text {th }}$ of heat at rather high temperatures $\left(300-680{ }^{\circ} \mathrm{C}\right.$ ). As a result, methanation serves to take heat away from the relatively inefficient cathode GT combined cycle $\left(800^{\circ} \mathrm{C}\right.$ TIT; waste heat $\left.<260{ }^{\circ} \mathrm{C}\right)$, and channel it instead to the anode exhaust and the methanator cooler, both of which ultimately provide waste heat at significantly higher temperatures. These effects yield improved bottoming cycle efficiency, and ultimately serve to make HICOM the thermodynami-cally superior configuration. It should be noted, however, that the difference in net power between the two cases is only a small frac-tion of their gross power, and thus seemingly small differences in assumptions or methodology have the potential to significantly alter the final results. In particular, the HRSC optimization soft-ware of Martelli et al. has proven to be an invaluable asset in this work since even slightly sub-optimal choices in bottoming cycle design or parameters could significantly bias the results and lead to inaccurate conclusions.

Table 1 indicates that the TREMP design is significantly less efficient (49.5\% LHV) than the DIRECT and HICOM plants; as will be seen below, it also has higher capital costs. For these reasons, our discussion of TREMP will be brief. Traditional solvent-based $\mathrm{CO}_{2}$ capture by physical absorption (upstream of the SOFC) is, as is wellknown, both thermodynamically and economically costly. Thus, TREMP is burdened with $38 \mathrm{MW}_{\mathrm{e}}$ extra auxiliary power consumption relative to the other two plants. Regarding power production, TREMP methanation yields a high concentration of $\mathrm{CH}_{4}$ in the SOFC fuel gas (37\%) which significantly reduces the cathode air flow and decreases the cathode GT power to only $21 \%\left(-103 \mathrm{MW}_{\mathrm{e}}\right)$ of that in DIRECT. As in HICOM, MP steam (170 $\mathrm{MW}_{\text {th }}$ ) is added to the syngas upstream of TREMP methanation (in the WGS feed). However, a significant fraction of the $\mathrm{CO}_{2}$ is removed in the AGR, and as a result, the specific heat capacity at constant pressure $c_{p}$ of the
SOFC fuel gas/anode exhaust remains largely unchanged (and the mass flow is reduced by $75 \%$ ) relative to that in DIRECT. Because the extremely small anode flow, the anode expander power is $10 \%$ smaller $\left(-12 \mathrm{MW}_{\mathrm{e}}\right)$ than in DIRECT, and the syngas expander is reduced by more than half $\left(-8 \mathrm{MW}_{\mathrm{e}}\right)$. While the TREMP HRSC has the highest first law efficiency (40.3\%) and highest output (43\% larger than DIRECT; $+79 \mathrm{MW}_{\mathrm{e}}$ ) of all three plants, it is unable to make up for all the other losses. As a result, the overall efficiency of the TREMP configuration is significantly lower than that of DIRECT and HICOM.

In summary, compared to the base case (DIRECT), syngas methanation upstream of the SOFC has a number of effects:

- it conveniently (and relatively inexpensively) preheats SOFC fuel gas to the high temperatures required for feeding the SOFC without subjecting it to undue thermal stresses;

- it reduces waste heat flowing into the relatively inefficient cathode GT circuit, instead releasing waste heat to the HRSC at higher temperatures in the methanation unit and the anode exhaust oxycombustor/expander line, significantly increasing the first law efficiency of the bottoming cycle;

- it effectively "upgrades" steam injected prior to methanation from lower to higher temperatures, further increasing the first law efficiency of waste heat recovery;

- it reduces the volumetric flow rate through the SOFC cathode, thus reducing size and capital cost of the SOFC and cathode turbomachinery; at the same time, it increases the flow rate through the SOFC anode, potentially increasing SOFC costs by a comparable amount. (Note that the reduced air flow has the potential to reduce SOFC performance, and that high water concentration in the anode has the potential to damage the cells.)

Given the salutary effect (on overall efficiency) of adding steam to the anode flow in the HICOM case, and the deleterious effect of removing $\mathrm{CO}_{2}$ from the anode flow, it may be worthwhile to explore increasing the flow rate of steam and/or $\mathrm{CO}_{2}$ in the SOFC feed gas beyond the levels considered here in HICOM.

The results also show that upstream methanation does not provide a significant increase to system efficiency, as was initially expected. Instead, it primarily shifts waste heat from the SOFC cath-ode to the methanator and SOFC anode, allowing it to be converted to electricity somewhat more efficiently (in the HICOM design) when using a well-designed HRSC. The HICOM configuration is slightly more efficient than the base case, but whether or not the increased complexity of upstream methanation can be justified economically will be explored in the following sections. The TREMP design involves significantly more complexity (and higher capital costs) and has lower efficiency; thus, it does not appear to warrant further investigation.

The main and actually only foreseen issue that could arise from employing a HICOM methanator upstream of the SOFC is the risk of catalyst degradation over the time. Contaminants from the syngas and/or bad thermal management of the reactor could lead to catalyst deactivation and sintering, respectively.

It is worthwhile to compare our results to those of Romano et al. (2011), who also investigated upstream TREMP methanation in an alternative design where the anode exhaust was decarbonized by cooling, WGS and recycling back to the AGR, yielding a $\mathrm{H}_{2}$ stream that was used to boost the TIT and efficiency of the cathode GT. Their overall plant efficiency of 51.6\% LHV is significantly higher than that of the TREMP plant investigated here. Also, the authors found out that the addition of the TREMP methanator is advantageous in terms of plant efficiency with respect to the IGFC plant presented in Spallina et al. (2011b), whose plant configuration is close to that of our DIRECT option, where syngas is directly fed into the SOFC and the exhaust anode gas is fired with pure oxygen for steam 
generation. It must be noted that their result is not in contradiction with ours: while we have included in our analysis the methanation process while keeping unchanged the power island configuration, Romano et al. (2011) have also improved the power island by replacing the oxy-combustion boiler with a more efficient gas turbine with up-to-date TIT exploiting both anode and cathode hot exhaust gases. In addition, compared to our analysis which is based on the energy-intensive Rectisol AGR process $\left(855.6 \mathrm{~kJ} / \mathrm{kg} \mathrm{CO}_{2}\right)$, Romano et al. (2011) adopt a chilled-Selexol process which is capable of capturing $\mathrm{CO}_{2}$ from syngas with a considerably lower energy consumption $\left(\sim 200 \mathrm{~kJ} / \mathrm{kg} \mathrm{CO} \mathrm{CO}_{2}\right.$ for AGR sections pre- and postSOFC; where the value of $416 \mathrm{~kJ} / \mathrm{kg} \mathrm{CO}$ reported in their work refers to $\mathrm{AGR}+\mathrm{CO}_{2}$ compression, from which we extrapolated the contri-bution of AGR units only). As a result, the efficiency gain found in their analysis (4.5 percentage points) must not be considered as the effect of the mere methanation process. Another relevant dif-ference between our work and that of Romano et al., is the SOFC pressurization level. In Romano et al. (2011), the SOFC pressure was increased from 20 to 34 bar in order to use the Selexol AGR process for post-SOFC $\mathrm{CO}_{2}$ removal. In our HICOM plant, post-SOFC CCS is accomplished without AGR and therefore the operating pres-sure is kept at 20 bar (and it could be even lowered in case of SOFC limitations).

\subsection{Discussion}

The goal of the U.S. DOE SECA program is large scale, efficient and clean power generation from domestic coal. In particular, its target plant efficiency for IGFC with carbon capture is 60\% HHV (Vora, 2011). The present work shows that this task is difficult even when using novel techniques to enhance performance, such as HICOM methanation and post-SOFC $\mathrm{CO}_{2}$ capture. In Fig. 4 the main energy flows in the HICOM plant are shown schematically, grouped into two primary sections. The gasifier and fuel processing section accounts for an overall LHV cold gas efficiency of almost 70\%; the power island (including the hybrid SOFC-GT group and the HRSC) accounts instead for an overall LHV efficiency of $\sim 80 \%$. The resulting overall LHV plant efficiency is $\sim 55 \%$ (or $\sim 52 \%$, HHV basis), that is the product of these two efficiencies. Considering that our power island employs already couples a SOFC-GT hybrid cycle (advanced technologies with a very high conversion efficiency) with an optimized HRSC bottoming cycle, further gains in this section will not be easy. Thus, reaching overall plant efficiency of $60 \%$ HHV (the goal set by SECA) will most likely require:

1. a more efficient gasification process (i.e., with a higher cold gas efficiency), such as relatively low temperature, catalytic hydrogasification, where the oxygen carrier is $\mathrm{H}_{2} \mathrm{O}$ rather than $\mathrm{O}_{2}(\mathrm{Li}$ et al., 2010), and

2. reducing the consumption of auxiliaries, especially the energyintensive ASU and pre-SOFC $\mathrm{CO}_{2}$ capture AGR units. One potential solution is to replace the ASU and post-SOFC $\mathrm{CO}_{2}$ capture units with an SOFC-integrated perovskite ion transfer membrane (ITM).

\subsection{Plant economics}

The economic viability of each plant was estimated using the EPRI TAG revenue requirement methodology (EPRI, 1993) in conjunction with an expanded version of the capital cost database of Kreutz et al. (2005a, 2008). We rely heavily on various NETL studies for component capital cost estimates. Costs for the gasifier island and syngas cleaning/processing sections are taken from a major NETL study on fossil fuel plants (DOE/NETL, 2010). For the cost of methanation reactors, we employ a recent NETL study of SNG production (DOE/NETL, 2011c). On the SOFC power island, capital
Table 3

Techno-economic assumptions employed in this study.

$\begin{array}{lc}\text { Coal price, \$/GJ HHV } & 2.04 \\ \text { Capacity factor } & 85 \% \\ \text { Capital charge rate (CCR), \% per year } & 14.4 \% \\ \text { Interest during construction, fraction of TPC } & 11.4 \% \\ \text { Construction period, year } & 3 \\ \text { O\&M, fraction of TPC per year } & 4 \% \\ \mathrm{CO}_{2} \text { transport \& storage, \$/tonne } & 6.1 \\ \text { SOFC module lifetime, year } & 5 \\ \text { SOFC degradation rate, ASR \% increase per } 1000 \mathrm{~h} & 0.2\end{array}$

(1) Interest during construction (IDC) is based on a 3-year construction schedule with equal, annual payments, and a discount rate of $10 \% /$ year.

(2) The capital charge rate is applied to total plant cost (TCP) + IDC.

costs for hot recirculators and the oxy-combustor were extrapolated from two recent NETL reports dealing with SOFC-based power cycles (DOE/NETL, 2011a,b). For the cathode heavy turbomachinery as well as for the oxy-combusted anode exhaust expander, our estimates are based on costs of the comparably-sized GE Frame 7FB and 7FA GTs (DOE/NETL, 2010; Kreutz et al., 2005b). The capital cost of the electric generator is assumed to be $25 \%$ of the total capital cost of the GT (GTW, 2003); the remaining capital cost (i.e., without generator) is assumed to be distributed as follows: compressor $=45 \%$, expander $=35 \%$ and balance of plant (combustor, controls and auxiliaries $)=20 \%$ (Kreutz et al., 2005b).

Our sources of cost data suggest that the uncertainty in our capital cost estimates is $\pm 30 \%$ for all equipment except for the SOFC power island, where a "target cost" approach is employed. As seen below, the difference in total plant cost (TPC) between the three cases is less than $30 \%$ of TPC. Nevertheless, because this is a comparative economic assessment in which the large majority of the plant components are unchanged from case to case, and all plants are subject to the same set of techno-economic assumptions, we believe that the relative cost differences among the three plants are significant. In contrast, absolute capital costs depend on numerous economic factors that defy generalization and thus are much more difficult to accurately ascertain; the reader is advised to interpret our absolute cost estimates with caution.

Economic parameters used to estimate the cost of producing electricity are given in Table 3. Note that all capital costs are escalated to mid-2007 US dollars using the Chemical Engineering Plant Cost Index.

In general, plant availability decreases with increasing plant complexity, negatively affecting its profitability. For example, the TREMP case includes a Rectisol-based $\mathrm{CO}_{2}$ capture process whose O\&M can be problematic (DOE Report, 2006). In contrast, the DIRECT and HICOM cases employ a technologically simpler postSOFC $\mathrm{CO}_{2}$ capture process. Unfortunately, there is insufficient data to quantify the effect of these differences on plant availability, and thus we assume that all three cases have the same capacity fac-tor of $85 \%$. The design and capital cost of SOFC modules (Table 4) were calculated following the costs estimates and methodology of NETL (DOE/NETL, 2011b; Milewski et al., 2011); additional costs for piping and insulation were taken from Siemens Westinghouse (Lundberg et al., 2000). The highly modular SOFC unit is designed as follows. Each pressurized module consists of 64 blocks of stacked planar cells with metallic interconnectors that serve as both bipo-lar plates and gas distributors. Each cell - the fundamental unit of a stack - has an active area of $550 \mathrm{~cm}^{2}$, and each block contains 96 cells with $5.28 \mathrm{~m}^{2}$ of active cell area. A module of 64 blocks produces $\sim 2 \mathrm{MW}$. (The entire SOFC unit comprises slightly more than 400 modules for a total output around $730 \mathrm{MW}_{\mathrm{e}}$.) Each module is enclosed in its own insulated pressure vessel, with an inverter, hot gas recirculators and heat-exchangers.

In our study we deliberately referred to large MW-size fuel cell power plants. The SOFC technology cost was sourced from NETL 


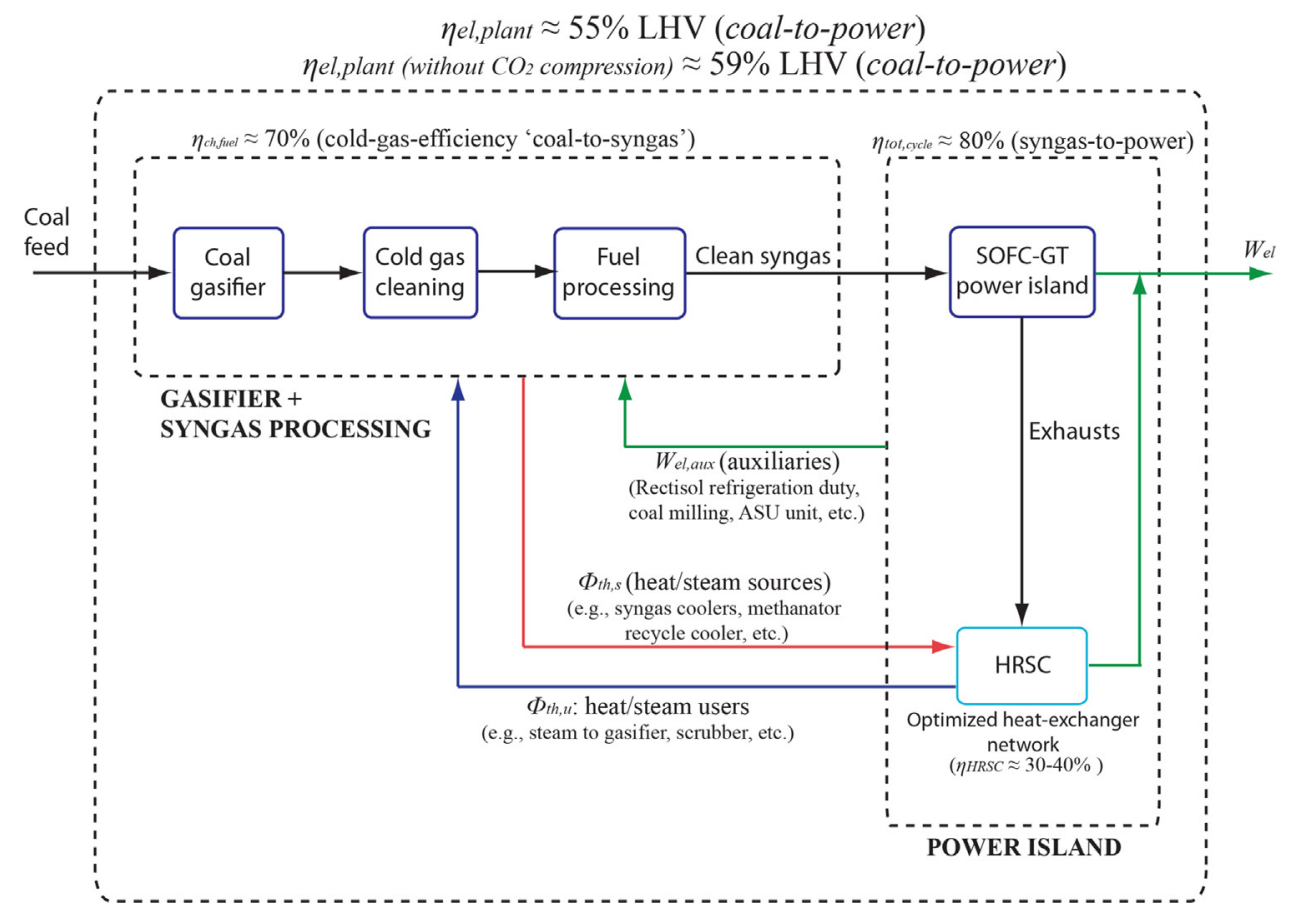

Fig. 4. Main energy flows in the IGFC HICOM plant.

Table 4

SOFC module cost ( $\$ / \mathrm{kWe})$ breakdown and main assumptions.

\begin{tabular}{lr}
\hline Integrated pres. SOFC blocks $^{\mathrm{a}}$ & 112 \\
Pressurized enclosure & 200 \\
DC/AC inverter & 82 \\
Piping and insulation & 125 \\
Transport and placement & 12 \\
Foundations at the site & 37 \\
Manufacturing cost & 30 \\
Bare-erected-cost (BEC) & 568 \\
Total-plant-cost (TPC) $^{\mathrm{b}}$ & 657
\end{tabular}

a SOFC cost calculated with a power density of $500 \mathrm{~mW} / \mathrm{cm}^{2}$ and specific active area cost of $0.054 \$ / \mathrm{cm}^{2}$ (Kuramochi et al., 2011; DOE/NETL, 2002; Thijssen and Thijssen, 2009).

b Engineering and contract fees add to the SOFC module BEC to yield the TPC. Contingencies fees are not accounted for as the SOFC cost presented here represents a target value.

studies under the SECA program (Ghezel-Ayagh, 2009) which have been systematically assessing the manufacturing cost of SOFC stack technology and related assemblies for multi-MW modules production.

Using the SOFC cost projections of Thijssen (2007), and furthermore assuming that early commercialization has advanced to production volumes exceeding $100 \mathrm{MW}$ installed per year, we obtain an estimated SOFC stack cost of $\sim 200$ 2007US $\$ / \mathrm{kW} .{ }^{4}$ By adding to this SOFC direct-manufactured cost other direct/indirect costs (for transportation, engineering, labor and materials for the site foundation and for installing the equipment on-site,

\footnotetext{
${ }^{4}$ In the report of Thijssen (2007), a manufacturing cost of the SOFC planar-type stack was derived by carefully taking into account the amount of raw materials used for manufacturing cell and stack components, insulation and enclosure materials, detailed cell and stack geometries and related manufacturing processes, stack elec-trical interconnection and mechanical assembly into larger power modules with common gas feeding/exhausting systems, and finally other BoP components (e.g., inverter, controls, etc.). The impact of scale-production was also included in the analysis to show how the manufacturing cost would lower by incrementing the yearly production rate.
}

additional BoP such as piping, inverter, etc.), an overall estimated SOFC installed cost of $\sim 650 \$ / \mathrm{kW}$ is calculated (see Table 5 ). This clearly represents a very optimistic projected (or "target") cost that should be viewed with skepticism considering that the current installed capital cost of a mature competitor, natural gas combined cycles (NGCC), is roughly $1000 \$ / \mathrm{kW}$. The reader is cautioned to treat the stack cost as a free parameter and to employ instead more accurate estimates as they become available. Today's stack costs are much higher as the commercialization of large SOFC systems $\left(>1 \mathrm{MW}_{\mathrm{e}}\right)$ has not started yet. Degradation issues are primarily hin-dering the path toward durable and reliable devices with a stack lifetime of 10 years or more (Yokokawa, 2013). However large field-demonstration projects have been already successful launched in Japan (Japanese group unveils, 2012) and Europe (EU Project).

The cost of high-temperature heat exchangers was estimated using data taken from chemical engineering handbooks (Turton et al., 2003; Green, 2007) and those reported in Kuramochi et al.(2011) and DOE/NETL (2002). For gas temperatures above $850{ }^{\circ} \mathrm{C}$ (i.e., the gas-gas recuperator after the oxy-combustor, with an hot stream inlet temperature around $1000-1050{ }^{\circ} \mathrm{C}$ depending on the specific plant design) a cost factor of 10 relative to the baseline cost of carbon steel construction was considered in order to account for a heat exchanger made of a high-temperature resistant alloy (e.g., an Inconel series alloy) (Turton et al., 2003). For heat-exchangers with hot streams up to $850{ }^{\circ} \mathrm{C}$ (this is the case of anode fuel recu-perator), a cost factor of 3 was used to scale from carbon steel (CS) to more high-temperature resistant stainless steel (SS) (e.g., AISI 314). The cost of heat-exchanger area included in the HRSG net-work was finally calculated as detailed in Table A.2. Spare SOFC capacity is assumed to be installed along with nominal capacity to compensate for stack degradation (DOE/NETL, 2011a). The sparing strategy is designed to keep the SOFC power output and efficiency nearly constant over time (an assumed constraint on the power plant operation). Operating the SOFC at constant voltage, i.e., reduc-ing the current as the cells degrade, is necessary to avoid increasing the stack cooling requirements over time (Thijssen and Thijssen, 2009). Cell ASR is assumed to increase steadily at a rate of $0.2 \%$ per $1000 \mathrm{~h}$; in order to maintain nearly constant operating voltage and 
Table 5

Performance and economics of coal-to-electricity plants.

\begin{tabular}{|c|c|c|c|c|c|c|}
\hline & \multirow{2}{*}{$\begin{array}{l}\text { Electricity } \\
\mathrm{MW}_{\mathrm{e}}\end{array}$} & \multirow[t]{2}{*}{$\eta(\mathrm{LHV})$} & \multicolumn{2}{|c|}{ TPC (2007 US\$) } & \multirow{2}{*}{$\begin{array}{l}\text { LCOE } \\
\text { \$/MWh }\end{array}$} & \multirow[t]{2}{*}{ IRR } \\
\hline & & & $\mathrm{M} \$$ & $\$ / \mathrm{kWe}$ & & \\
\hline PC-CCS & 546 & $28.6 \%$ & 1617 & 2961 & 121.4 & $4.5 \%$ \\
\hline IGCC-CCS & 517 & $33.5 \%$ & 1424 & 3069 & 109.6 & $7.8 \%$ \\
\hline IGFC DIRECT $^{\mathrm{a}}$ & 984 & $53.8 \%$ & 2047 & 2317 & 78.8 & $22.1 \%$ \\
\hline IGFC TREMPa & 905 & $49.5 \%$ & 2124 & 2616 & 89.4 & $17.8 \%$ \\
\hline IGFC HICOM $^{\mathrm{a}}$ & 998 & $54.6 \%$ & 2046 & 2283 & 77.6 & $22.6 \%$ \\
\hline
\end{tabular}

a SOFC cost at $657 \$ / \mathrm{kW}$ AC (active area @ $0.054 \$ / \mathrm{cm}^{2}$ ).

Table 6

Comparison of the electricity cost components between the HICOM plant and the baseline IGCC case.

\begin{tabular}{lcc}
\hline Electricity cost components, 2007\$/MWh & IGCC-CCS & IGFC HICOM $^{\mathrm{a}}$ \\
\hline Installed capital (at 14.38\% of TPI) & 59.22 & 44.07 \\
O\&M (at 4\% of TPC per year) & 14.79 & 11.00 \\
O\&M SOFC modules & - & 3.00 \\
Coal/biomass (at 2.04/5\$/GJ, HHV) & 22.90 & 14.07 \\
$\mathrm{CO}_{2}$ emissions (at 50\$/tonne $\mathrm{CO}_{2}$ ) & 6.80 & 1.90 \\
$\mathrm{CO}_{2}$ disposal (at 6.1\$/tonne $\left.\mathrm{CO}_{2}\right)$ & 5.94 & 3.59 \\
Levelized cost of electricity $(\mathrm{LCOE})$ & 109.65 & 77.64 \\
\hline
\end{tabular}

a SOFC cost at $657 \$ / \mathrm{kW}$ AC.

plant power output, the cell current density is decreased at regular intervals (e.g., every $1000 \mathrm{~h}$ ) while enabling spare cell capacity. We assume that $100 \%$ of the initial SOFC capacity is replaced every 5 years. With a degradation rate of $0.2 \%$ per $1000 \mathrm{~h}$, the overall stack degradation at the end of life is $\sim 7 \%$. Note that spare stack capacity that is gradually activated during the overall plant lifetime is replaced also every five years.

\subsubsection{Plant economic performance}

A summary of the economic performance of the three IGFC plants is given in Table 5. The total plant cost (TPC), or "overnight construction cost", given in Table 5 for each case, includes engineering and overhead, general facilities, balance of plant, and both process and project contingencies. For comparison and ref-erence, the results for a Shell-based IGCC-CCS power plant are also shown. The thermodynamic performance of the IGCC-CCS plant considered here equals that reported in (DOE/NETL, 2010). However, the levelized cost of electricity (LCOE) was calculated using the economic/financial assumptions used in this study. Note that, at the assumed SECA target SOFC module cost of $657 \$ / \mathrm{kW} \mathrm{AC}$, all three IGFC plants produce decarbonized electricity at costs appreciably below that of IGCC-CCS. As expected from its supe-rior thermodynamic performance and relatively straightforward gas cleaning/processing configuration, the HICOM case is seen to achieve the lowest $\$ / \mathrm{kW}$ and LCOE (and highest internal rate of return on equity, IRR) of all plants. However, the economic advantage of HICOM over the base case DIRECT is so small that it can be neglected. Whether a plant designer would choose HICOM over DIRECT is likely to depend upon factors - such as plant availability or effect of added steam on the anode or the comparative costs of the two HRSCs - that are not accounted for in this analysis.

Table 6 provides a more detailed comparison of the electric-ity cost components between the IGFC cases and the reference IGCCCCS plant. Even though the overnight cost of IGCC-CCS is roughly 25\% less than the HICOM case, the much higher efficiency of the latter plant (true for all IGFC cases) yields lower specific costs ( $\$$ MWh) in every category. Among the IGFC configurations studied, the main drivers for better economic performance of the HICOM case are the lower TPC (and O\&M costs) and the higher plant efficiency, i.e., lower fuel costs. In Table 7, TPC is disaggregated by major components for the three IGFC cases. Notably, the SOFC power island contributes for nearly one-third of the total plant cost.
Table 7

Capital costs sheet for the IGFC cases analyzed in this study.

\begin{tabular}{|c|c|c|c|c|}
\hline \multirow[t]{2}{*}{ Item } & \multirow{2}{*}{$\begin{array}{l}\text { Plant } \\
\text { component/section }\end{array}$} & \multicolumn{3}{|c|}{ Overnight cost with BOP (M\$) } \\
\hline & & DIRECT & TREMP & HICOM \\
\hline 1 & SOFC power core & 496 & 499 & 490 \\
\hline 2 & Oxy-combustor & 16 & 16 & 16 \\
\hline 3 & Turbomachinary & 183 & 93 & 134 \\
\hline 4 & $\begin{array}{l}\text { Heat-exchangers (fuel } \\
\text { recuperator, air } \\
\text { pre-heater) }\end{array}$ & 21 & 21 & 22 \\
\hline 5 & $\begin{array}{l}\text { Syngas cleaning and } \\
\text { processing upstream of } \\
\text { the SOFC }\end{array}$ & 170 & 326 & 202 \\
\hline 6 & $\begin{array}{l}\text { Gasifier island } \\
\text { (including ASU) }\end{array}$ & 877 & 877 & 877 \\
\hline 7 & $\mathrm{CO}_{2}$ compression & 122 & 72 & 122 \\
\hline \multirow[t]{2}{*}{8} & $\begin{array}{l}\text { Heat recovery network } \\
\text { and steam cycle }\end{array}$ & 160 & 220 & 183 \\
\hline & $\begin{array}{l}\text { Total plant cost (TCP), } \\
\text { 2007M\$ }\end{array}$ & 2047 & 2124 & 2046 \\
\hline
\end{tabular}

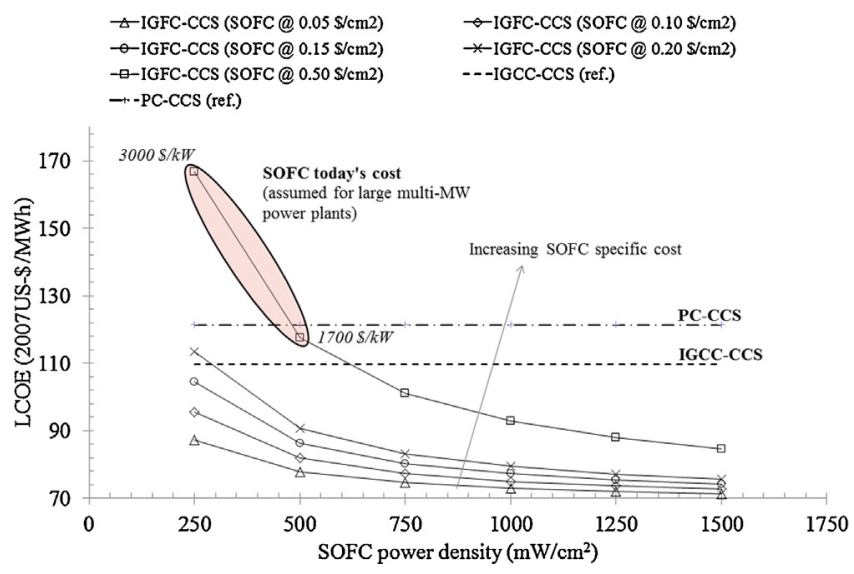

Fig. 5. Impact of SOFC power density and specific bulk cost on the LCOE of HICOM plant.

Compared to the other two other IGFC cases analyzed, the TREMP case has the highest installed capital cost primarily because of the relatively expensive Rectisol unit (included in the syngas cleaning and processing cost item in Table 7) that captures $\mathrm{CO}_{2}$ and $\mathrm{H}_{2} \mathrm{~S}$ upstream of the SOFC. Finally, the TREMP case has a lower cap-ital cost for turbomachinery than the other IGFC cases due to the reduced flow rates of syngas and cathode air feeding the SOFC; how-ever, its HSRC costs are somewhat higher due to a more expensive network of HXs.

Effect of the power density and SOFC bulk cost on the LCOE for the HICOM case A reduction in the cost of SOFC module could result from increasing the single-cell power density as power density translates to less active area required. Fig. 5 shows how the LCOE for the HICOM case is affected by a varying SOFC power density from 
250 to $1250 \mathrm{~mW} / \mathrm{cm}^{2}$. The lower bound of this range is a plausible estimate of current SOFC performance, while $500 \mathrm{~mW} / \mathrm{cm}^{2}$ is used in all cost calculations presented here. (Note Fig. 5 assumes constant cell efficiency; thus, higher power density implies enhanced ASR and/or current density).

In Fig. 5 the specific cost of the SOFC cells is also varied from the target cost of $0.054 \$ / \mathrm{cm}^{2}$ (consistent with NETL assumptions (Campanari et al., 2010; Franzoni et al., 2008)) to a value almost ten times higher. With the highest active area cost $\left(0.50 \$ / \mathrm{cm}^{2}\right)$, a power density of $250-500 \mathrm{~mW} / \mathrm{cm}^{2}$ yields an SOFC module cost of $1700-3000 \$ / \mathrm{kW}$ (circled line in Fig. 5). This range represents what might be considered a today's SOFC cost, implying mature SOFC technology ready for deployment at large scales, but not yet benefitting from the economic advantages of mass production at large scales. Costs in the range of $3000-8000 \$ / \mathrm{kW}$, with a power density of $\sim 250 \mathrm{~mW} / \mathrm{cm}^{2}$ and a specific area cost that exceeds $0.50 \$ / \mathrm{cm}^{2}$ (up to $\sim 3.0 \$ / \mathrm{cm}^{2}$ ) apply instead for residential or distributed generation (DG) systems. At these relatively small to medium scales, the cost benefits of mass production are not yet realized. According to manufacturers, current SOFC production costs are already close to the "today's" categorization described above in the text. Bloom Energy (US) claimed in 2010 (Bloom Energy, 2011) that their SOFC module costs were $7000-8000 \$ / \mathrm{kWe}$ and the CEO of SOFCpower (IT/CH) asserted that SOFC costs of $\sim 3000 \$ / \mathrm{kWe}$ could be achieved immediately if large production volumes were available (Ravagni, 2011). Looking at Molten Carbonate Fuel Cells (MFC) systems - a technology relatively similar to the SOFC in term of operating temperature, materials used and BoP required, but more mature and being successfully commercialized by Fuel Cell Energy (Fuel Cell Energy, 2014) - installed system costs range between in the interval 2500-4500 2012US\$/kW (Dionissios et al, 2012).

Since the HICOM case resulted as the most performing one both in energy and economic terms, sensitivity analyses around it will be presented in what following in this paper.

Fig. 5 also indicates that, although LCOE is fairly sensitive to power density at high specific costs (e.g., $0.50 \$ / \mathrm{cm}^{2}$ ), at the tar-get cost of $0.054 \$ / \mathrm{cm}^{2}$, the SOFC module costs are dominated by BOP, and are thus quite insensitive to developments that increase power density (better electrodes, materials, etc.). In Fig. 4, given the assumption of a fuel cell stack operating always at the same efficiency, the power density range spanning on the $x$-axis from 250 to $1500 \mathrm{~mW} / \mathrm{cm}^{2}$ corresponds to an ASR varying from 0.57 to $0.09 \Omega \mathrm{cm}^{2}$ and a current density from 0.32 to $1.90 \mathrm{~A} / \mathrm{cm}^{2}$.

Trends similar to those shown in Fig. 4 for the HICOM case hold for the DIRECT and TREMP plants.

\subsubsection{Effect of stack replacement period on IGFC economic performance}

Fig. 6 analyses how stack degradation rate and replacement period affect overall plant economics. At any given degradation ratio there exists an optimal stack replacement period that minimizes the LCOE, e.g., $\sim 5$ years with a degradation rate of $0.2 \%$ per 1000 h. Notably, an enhanced degradation rate of the SOFC stack from $0.2 \%$ (the target value for commercial stacks) to $1 \%$ (a typi-cal value for current stacks) per $1000 \mathrm{hr}$ significantly increases the required percentage of installed spare capacity (from roughly $12 \%$ to $25 \%$ ) and thus the LCOE, from 77 to 84 US\$/MWh.

\subsubsection{Effect of carbon tax on IGFC economics}

Fig. 7 shows how price on greenhouse gas (GHG) emissions affects the LCOE for the IGFC HICOM plant as well those of other coal power plants. Economic data for pulverized coal (PC) plants and IGCC were retrieved from Larson et al. (2012), while detailed plant designs can be found in the NETL report on coal power plants (DOE/NETL, 2010).

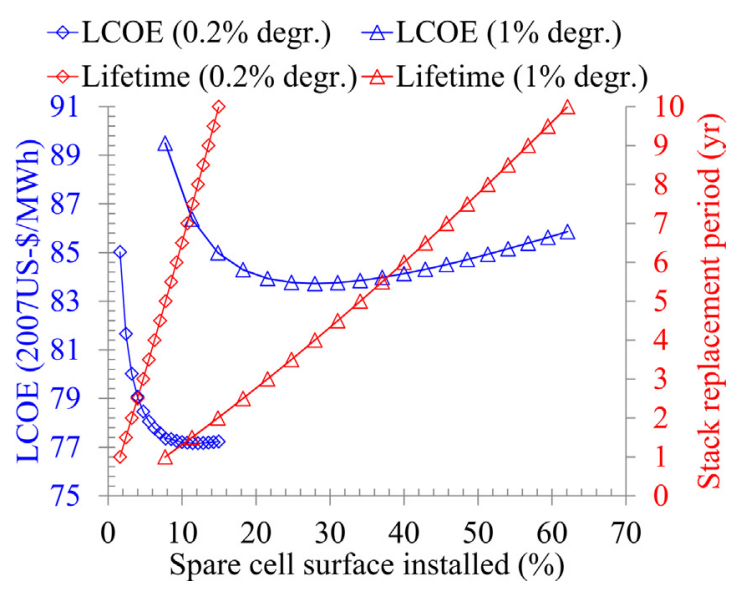

Fig. 6. Impact of cell stack replacement period (with $0.2 \%$ and $1.0 \%$ per $1000 \mathrm{~h}$ ASR degradation, respectively) on the economic performance of HICOM plant.

$$
\begin{array}{ll}
\rightarrow-\mathrm{PC}-\mathrm{V} & ----\mathrm{PC}-\mathrm{CCS} \\
-\mathrm{IGCC}-\mathrm{V} & --\Delta-\mathrm{IGCC}-\mathrm{CCS} \\
\leadsto-\mathrm{IGFC}-\mathrm{HICOM}-\mathrm{V} & --*-\text { IGFC-HICOM-CCS }
\end{array}
$$

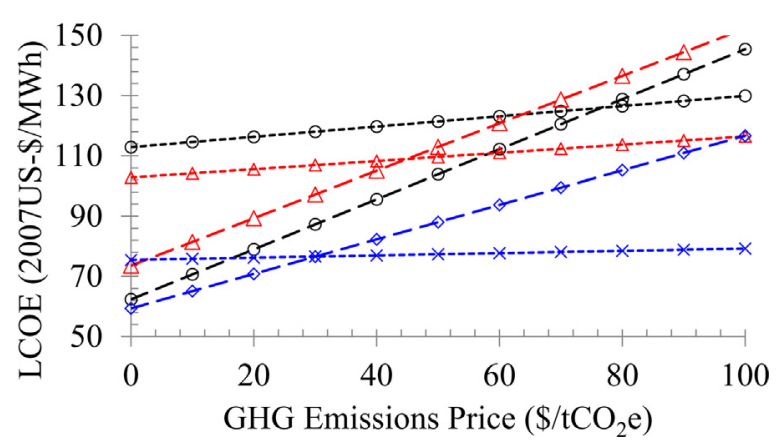

Fig. 7. Impact of the 'carbon tax' on the LCOE of conventional and fuel cell based coal plants.

The IGFC HICOM plant without $\mathrm{CO}_{2}$ capture (IGFC-HICOM-V) was modeled similarly as the other IGFC plants (with CCS) in this study. Only the HRSC and the heat-exchanger network were not optimized through the algorithm of Martelli et al., rather it was assumed an overall HRSC first law efficiency of $40 \%$. (Note that for the HICOM plant with CCS, the optimized case gave an efficiency of $\sim 38 \%$, that is quite close.) The plant layout without CCS is essentially the same as for the plant version with CCS, expect that the anode and cathode exhaust streams exiting the SOFC are mixed and burnt together. Thus only one hot exhaust feed is coming out from the SOFC power island and serving the HRSG rather the two separate feeds (the oxy-combusted anode exhaust and cathode exhaust, respectively) as for the CCS case.

From Fig. 7 it is worth to observe that if the SOFC NETL-SECA target cost $\left(0.054 \$ / \mathrm{cm}^{2}\right.$, corresponding to $657 \$ / \mathrm{kW}$ AC referring to the SOFC power module only, or $1700 \$ / \mathrm{kW}$ referring to the whole IGFC power plant) were achieved, the resulting $\mathrm{CO}_{2}$ break-even price, $\sim 30 \$ / \mathrm{tCO}_{2} \mathrm{e}$, is seen to be significantly lower for IGFC than for both PC and IGCC plants, highlighting the potential low cost of $\mathrm{CO}_{2}$ capture via oxy-combustion of the SOFC anode exhaust.

\section{Discussion}

The methanation process (in case of a multi-staged process, not investigated in this study) could be used to control the amount of endothermic reforming within the stack, thus providing an additional degree of freedom to control its thermal behavior. The both 
highly energy intensive and costly co-capture of $\mathrm{H}_{2} \mathrm{~S}$ and $\mathrm{CO}_{2}$ in the Rectisol unit plays a huge penalty for the plant. It is worth to mention here the field experience of the SNG plant of Great Plains (US), employing a full multi-reactors TREMP methanation process; in this real plant, the Rectisol section upstream of the TREMP was reported to be the bottleneck of the whole plant (US DOE, 2006) due to several malfunctioning/maintenance issues. Notably, the HICOM plant configuration proposed in this study limits the duty of the Rectisol-based AGR to sulfur compounds removal only, while main-taining the possibility to enrich with methane the syngas stream by using a high CO-tolerant catalyst.

It is worth noting that the slightly higher electrical efficiency of the HICOM case (compared the base case, DIRECT) does not yield improved economics; the LCOE is slightly higher for HICOM than for DIRECT (see Tables 1 and 5). In short, methanation can be used to shift (to same extent) thermal and electrical loads to completely different plant sections without necessarily altering plant efficiency and/or profitability. This may be both a benefit and limitation of manipulating the syngas composition via methanation. In Section 5 we will summarize the potential advantages of shifting loads within the power plant.

It is useful to compare our results on energy and economic performance with those of previous studies (taking into account the different technical and economic assumptions). NETL (Gerdes et al., 2009) calculated a HHV efficiency of $56.1 \%$ for a pressur-ized IGFC cycle with CCS, compared to $52.1 \%$ for case HICOM; NETL's LCOE of $79 \$ / M W h$ (reference year 2007) is essentially equal to that of HICOM. DOE/NETL (2011b) report HHV efficiencies of $49-51 \%$ for IGFC plants with CCS, and LCOEs slightly higher than 70\$/ MWh; both results are comparable to those reported here. The system studied by Gerdes et al. (2009) exhibits a higher overall efficiency that any of the plants investigated here, but assumes a novel catalytic steam- $\mathrm{O}_{2}$ gasifier with a notably high cold gas efficiency (and elevated methane concentration in the raw syngas) instead of the less efficient commercial Shell gasifier used here.

The cost framework used in this work enabled us to estimate the cost differences among the three investigated IGFC cases, and to quantify if the proposed process modifications make economic (as well as thermodynamic) sense.

It is worth highlighting that great uncertainty is still present around the future cost of SOFC technology. In our analysis, a rather optimistic projected (or "target") estimate was used according to NETL calculations. In both Figs. 5 and 7, it was shown that such a target cost $(657 \$ / \mathrm{kW}$ for the module unit) would pose the SOFC as highly competitive against business-as-usual technologies, potentially claiming for a lower carbon-tax in order to make CCS economically (Fig. 7). In Fig. 5 the cost was varied to attempt a simulation of what the today's cost could be for large scale installations not yet benefitting of economies of scale.

As concluding remark, the reader is advised to look at the economic results in the previous sections with the following mindset: the SOFC target cost is the one that would be ultimately required for fuel cell to compete with conventional power technologies (e.g., gas-turbine combined cycle). Proving the accuracy of NETL cost estimations and solving technical challenges con-nected with high-temperature fuel cells, such as SOFC, remain therefore the key questions to be addressed and clarified in the next future.

\section{Conclusions}

In IGFC plants based on oxygen-blown entrained flow gasifiers that produce syngas with a low methane content, methanation upstream of the SOFC has a number of interesting effects:
- the air flow rate required to cool the stack is reduced, potentially decreasing the footprint of the power island;

- endothermic reforming of methane directly within the stack helps reduce thermal gradients;

- upstream methanation is an effective way to pre-heat the fuel gas upstream of the stack;

- in designs employing post-SOFC $\mathrm{CO}_{2}$ capture, the size of the cathode turbomachinery is reduced.

In particular, HICOM methanation is seen to increase overall plant efficiency, but have little effect on LCOE; in contrast TREMP methanation yields both lower efficiency and higher LCOE than the base case (DIRECT), as it implies the necessity of shifting the syngas and removing $\mathrm{CO}_{2}$ with an energy-intensive absorption process. Thus, the addition of a TREMP methanation process into an IGFC plant with $\mathrm{CO}_{2}$ capture may be advantageous compared to the direct-use option if (i) a low-energy-consumption AGR process is used, (ii) the exploitation of the unconverted anode and cathode gases through a cooled gas turbine, as previously shown by Lanzini et al. (2012).

Compared to other coal-fired power generating technologies (PC and IGCC), the high capital cost of the SOFC power island in IGFC is offset by its high conversion efficiency and low cost of post-combustion $\mathrm{CO}_{2}$ capture. Given our many performance and economic assumptions, the results indicate that, at an SOFC module cost of $1700 \$ / \mathrm{kW}$ (corresponding to an active cell/stack area cost of $0.054 \$ / \mathrm{cm}^{2}$ ), the LCOE of the IGFC HICOM case would be comparable to that of IGCC-CCS. This suggests that IGFC-CCS plants based on commercial entrained flow gasifiers may have an important role to play as future low carbon fossil-fueled power generators in a carbon-constrained world. Although SOFCs are not yet eco-nomically viable as commercial power generators, the steadily increasing performance of planar stacks (that have the potential to boost power densities to $500 \mathrm{~mW} / \mathrm{cm}^{2}$ within the next few years), along with the development of high volume production techniques, could lead to future IGFC-CCS plants that are cost competitive with IGCC-CCS and PC-CCS.

Looking forward, determining the optimal operating pressure for the IGFC-CCS is an important task for future work. We also note that pressurized SOFCs are well suited to integration with perovskite-based ion transfer membranes (ITM) reactors, e.g., those developed by Air Products and Chemicals Inc. Notably, an ITM placed downstream of the SOFC could recover sufficient oxygen (from the hot pressurized cathode exhaust) to feed both the gasifier and the anode's oxy-combustor. This would obviate the costly and energy-intensive ASU, potentially leading to further improvements in both plant efficiency and profitability.

\section{Acknowledgments}

One of the authors, Andrea Lanzini, is grateful to the US/Italy Fulbright Commission, IIE grant ID 15103958 for supporting his research as a visiting graduate student at Princeton University, within the Energy Systems Analysis Group of the Princeton Environmental Institute. Prof. Robert Socolow and the other senior members of the Princeton Energy Group (Dr. Bob Williams and Dr. Eric Larson) are also gratefully acknowledged for their support and fruitful discussions around the topics presented.

\section{Appendix.}

In the following section are provided the process design parameters assumptions used for plant performance calculations in ASPEN Plus (Table A.1). The detailed cost spreadsheet built to evaluate the HICOM plant economic performance is also given (Table A.2). 
Table A.1

Process design parameter assumptions for ASPEN Plus.

\begin{tabular}{|c|c|}
\hline Unit & Description \\
\hline Air separation unit (ASU) & $\begin{array}{l}\text { Cryogenic (stand-alone) air separation for the oxy-combustor: } 99.5 \text { (vol.\%) } \mathrm{O}_{2} \text { production (Franzoni et al., 2008); power } \\
\left(\mathrm{kWh} / \mathrm{t} \text { pure } \mathrm{O}_{2} \text { at atmospheric pressure) }=26.32 \text { (Singhal, 1999). }\right.\end{array}$ \\
\hline Coal milling \& handling + ash handling & Electricity requirement $=0.24 \%$ of input coal $\left(\mathrm{MW}_{\mathrm{el}} / \mathrm{MW}\left(\mathrm{HHV}_{\text {coal }}\right)\right)($ Singhal, 1999$)$ \\
\hline Fresh air composition & Air composition (vol.\%): $\mathrm{O}_{2}, 20.95 ; \mathrm{N}_{2}, 78.12 ; \mathrm{Ar}=0.93$ \\
\hline Coal composition & Illinois \#6 bituminous coal, no. 2 (Singhal, 1999). \\
\hline Gasifier & $\begin{array}{l}\text { Shell gasifier with convective syngas coolers }\left(T=1391^{\circ} \mathrm{C}, p=38.5 \text { bar }\right) \text {. Losses: } 1.5 \% \text { of the inlet coal HHV as heat loss at the } \\
\text { membrane wall; } 1 \% \text { of scrubbed syngas for coal drying. }\end{array}$ \\
\hline Rectisol unit & $\begin{array}{l}\text { Physical } \mathrm{CO}_{2} \text { and sulfur absorption with chilled methanol at }-40{ }^{\circ} \mathrm{C} \text {; syngas recycle is applied to minimize the amount of fuel } \\
\text { co-absorbed with the } \mathrm{CO}_{2} \mathrm{CO}_{2} \text { is then separated and compressed from a cascade of four flash separators (Foger, 2010). }\end{array}$ \\
\hline WGS unit & $\begin{array}{l}\text { 2-Stage WGS adiabatic reactor with bypass line and an inlet steam/CO ratio of } 2.1 \text { at each stage; the outlet syngas has an } \\
\text { imposed } \mathrm{H}_{2} / \mathrm{CO} \text { ratio of } 3 \text { as requested downstream by the TREMPTM catalyst of the methanator. The inlet syngas temperature } \\
\text { in the reactor is } 250^{\circ} \mathrm{C} \text {. }\end{array}$ \\
\hline Methanator with TREMP ${ }^{\mathrm{TM}}$ catalyst & $\begin{array}{l}\text { Single adiabatic reactor with inter-cooled recycle with an inlet } \mathrm{H}_{2} / \mathrm{CO} \text { ratio of } 3 \text {. The catalyst is the Ni-based one used in the } \\
\text { TREMPTM }^{\mathrm{TM}} \text { process by Haldor TOPSOE. The inlet syngas temperature in the reactor is } 250^{\circ} \mathrm{C} \text {. }\end{array}$ \\
\hline Methanator with HICOM catalyst & $\begin{array}{l}\text { High CO direct methanation (HICOM) Ni-based catalyst employed in single adiabatic reactor with inter-cooled recycle; an inlet } \\
\text { steam/CO ratio of } 1.5 \text { is used to avoid coking. The inlet syngas temperature in the reactor is } 250^{\circ} \mathrm{C} \text {. }\end{array}$ \\
\hline GT group in SOFC compressor & Uncooled compressor: $\eta_{i s}=0.89 ;$ uncooled turbine: $\eta_{i s}=0.92 ; \eta_{\text {mech }+e l}=0.98$ \\
\hline Anode expander & Steam $/ \mathrm{CO}_{2}$ expander (uncooled, with TIT max. set to $850^{\circ} \mathrm{C}$ ): $\eta_{i s}=0.92 ; \eta_{\text {mech }+e l}=0.98$. \\
\hline Oxy-combustor & Oxygen excess stoichiometry: 1.01 mole (GTW, 2003). \\
\hline $\mathrm{CO}_{2}$ compression train & $\begin{array}{l}4 \text { stages inter-cooled at } 30^{\circ} \mathrm{C} \text { with liquid water knock-out. Pressure ratio of each stage is } \beta=1.21 \text { and discharge pressure is of } \\
43 \text { bar. } \eta_{\text {pol }}=0.73 ; \eta_{\text {mech }+e l}=0.95 \text {. Last stage (from } 43 \text { to } 150 \text { bar): } \eta_{\text {is }}=0.75 ; \eta_{\text {mech }}=0.98 \text {. }\end{array}$ \\
\hline
\end{tabular}

Table A.2

Detailed overnight cost sheet for the HICOM plant.

\begin{tabular}{|c|c|c|c|c|c|c|c|c|c|}
\hline Item & Plant component & Scaling parameter & $\begin{array}{l}\text { Base } \\
\text { capacity, } \\
\text { So }\end{array}$ & $\begin{array}{l}\text { Cost } \\
\text { scaling } \\
\text { factor }\end{array}$ & $\begin{array}{l}\text { Base cost, } \\
\text { Co }(2007 \\
\text { MS })\end{array}$ & $\begin{array}{l}\text { Required } \\
\text { capacity }\end{array}$ & $\begin{array}{l}\text { Component } \\
\text { OC cost } \\
\text { (MS) }\end{array}$ & $\begin{array}{l}\text { Component } \\
\text { OC cost } \\
\text { with BOP } \\
\text { (MS) }\end{array}$ & $\begin{array}{l}\text { Component } \\
\text { OC cost } \\
\text { with BOP } \\
\text { (S/kWe) }\end{array}$ \\
\hline 1 & SOFCpower core & & & & & & & & \\
\hline 1.1 & $\begin{array}{l}\text { Pressurized SOFC } \\
\text { (active area + BoP) }\end{array}$ & $\begin{array}{l}\text { SOFC AC power output, } \\
\text { MW }_{\mathrm{e}}\end{array}$ & 1.0 & 1.00 & 0.66 & 693.1 & 455.7 & 455.7 & 456.6 \\
\hline \multirow[t]{2}{*}{1.2} & $\begin{array}{l}\text { Pres. SOFC spare } \\
\text { capacity (active area } \\
\text { only) }\end{array}$ & $\begin{array}{l}\text { SOFC AC power output, } \\
\mathrm{MW}_{\mathrm{e}}\end{array}$ & 1.0 & 1.00 & 0.05 & 693.1 & 33.9 & 33.9 & 34.0 \\
\hline & SUBTOTAL 1 & & & & & & & 489.6 & 490.6 \\
\hline 2 & Burners & & & & & & & & \\
\hline 2.1 & Oxy-combustor & Heat duty, $\mathrm{MW}_{\mathrm{th}}$ & 95.2 & 0.73 & 7.1 & 232.7 & 13.7 & 16.2 & 16.2 \\
\hline & SUBTOTAL 2 & & & & & & 13.7 & 16.2 & 16.2 \\
\hline 3 & Turbomachinary & & & & & & & & \\
\hline 3.1 & Anode recirculator & $\begin{array}{l}\text { Anode exhaust vol. } \\
\text { flow, kmol/s }\end{array}$ & 4.3 & 1.00 & 0.5 & 0.0 & 0.0 & 0.0 & 0.0 \\
\hline 3.2 & Cathode recirculator & $\begin{array}{l}\text { Cathode exhaust vol. } \\
\text { flow, kmol/s }\end{array}$ & 21.7 & 1.00 & 5.1 & 31.1 & 7.3 & 8.7 & 8.7 \\
\hline 3.3 & Cathode air compressor & Power output, $\mathrm{MW}_{\mathrm{e}}$ & 232.0 & 0.80 & 23.8 & 332.7 & 34.0 & 40.2 & 40.3 \\
\hline 3.4 & Cathode expander & Power output, $\mathrm{MW}_{\mathrm{e}}$ & 464.0 & 0.80 & 29.2 & 385.7 & 25.2 & 29.7 & 29.8 \\
\hline 3.5 & Syngas expander & Power output, $\mathrm{MW}_{\mathrm{e}}$ & 6.5 & 0.67 & 8.0 & 19.1 & 16.4 & 19.4 & 19.4 \\
\hline \multirow[t]{2}{*}{3.6} & $\begin{array}{l}\text { Oxy-combusted anode } \\
\text { expander }\end{array}$ & Power output, $\mathrm{MW}_{\mathrm{e}}$ & 171.7 & 0.80 & 27.6 & 191.0 & 30.0 & 35.5 & 35.6 \\
\hline & SUBTOTAL 3 & & & & & & 112.9 & 133.5 & 133.8 \\
\hline 4 & Heat-exhangers & & & & & & & & \\
\hline 4.1 & $\begin{array}{l}\text { High-T Inconel alloy EK } \\
\text { (oxy-combusted } \\
\text { exhaust recuperator) }\end{array}$ & Exchange area, $\mathrm{m}$ & 100.0 & 0.36 & 2.9 & 8706.1 & 14.6 & 17.3 & 17.3 \\
\hline \multirow[t]{2}{*}{4.2} & $\begin{array}{l}\text { Medium-T SS EK (fuel } \\
\text { recuperator) }\end{array}$ & Exchange area, $\mathrm{m}$ & 100.0 & 0.36 & 0.9 & 7082.8 & 4.1 & 4.8 & 4.8 \\
\hline & SUBTOTAL 4 & & & & & & 18.7 & 22.1 & 22.1 \\
\hline 5 & Reactors & & & & & & & & \\
\hline 5.1 & $\begin{array}{l}\text { Single reactor } \\
\text { methanator with } \\
\text { recycle }\end{array}$ & $\begin{array}{l}\text { Methanated syngas } \\
\text { flow, } \mathrm{kmol} / \mathrm{s}\end{array}$ & 2.3 & 0.84 & 63.1 & 0.8 & 27.0 & 32.0 & 32.0 \\
\hline 5.2 & $\begin{array}{l}\text { Gas cleanup BOP }(\mathrm{Hg} \\
\text { removal, piping, } \\
\text { foundations })\end{array}$ & ARcoal, $\mathrm{MW}_{\text {th }} \mathrm{LHV}$ & 815.2 & 0.67 & 5.5 & 1827.8 & 11.1 & 13.1 & 13.1 \\
\hline 5.3 & Sulfinol $\left(\mathrm{H}_{2} \mathrm{~S}\right.$ removal $)$ & $\mathrm{H}_{2} \mathrm{~S}, \mathrm{kmol} / \mathrm{s}$ & 0.04 & 0.67 & 85.2 & 0.1 & 117.3 & 138.7 & 139.0 \\
\hline 5.4 & Sulfur polishing & Syngas, kmol/s & 4.8 & 0.67 & 3.8 & 6.1 & 5.2 & 6.1 & 6.1 \\
\hline \multirow[t]{2}{*}{5.5} & Claus plant & $\mathrm{S}$ input, mt/day & 136.5 & 0.67 & 33.8 & 18.0 & 10.2 & 12.1 & 12.1 \\
\hline & SUBTOTAL 5 & & & & & & 170.7 & 201.9 & 202.4 \\
\hline 6 & Shell gasifier & & & & & & & & \\
\hline 6.1 & Coal handling & AR coal, mt/day & 5447.2 & 0.67 & 36.4 & 1827.8 & 20.5 & 24.3 & 24.4 \\
\hline 6.2 & $\begin{array}{l}\text { Coal preparation \& } \\
\text { feeding }\end{array}$ & AR coal, mt/day & 2463.7 & 0.67 & 91.6 & 1827.8 & 87.9 & 104.0 & 104.2 \\
\hline
\end{tabular}


Table A.2 (Continued)

\begin{tabular}{|c|c|c|c|c|c|c|c|c|c|}
\hline Item & Plant component & Scaling parameter & $\begin{array}{l}\text { Base } \\
\text { capacity, } \\
\text { So }\end{array}$ & $\begin{array}{l}\text { Cost } \\
\text { scaling } \\
\text { factor }\end{array}$ & $\begin{array}{l}\text { Base cost, } \\
\text { Co }(2007 \\
\text { MS })\end{array}$ & $\begin{array}{l}\text { Required } \\
\text { capacity }\end{array}$ & $\begin{array}{l}\text { Component } \\
\text { OC cost } \\
\text { (MS) }\end{array}$ & $\begin{array}{l}\text { Component } \\
\text { OC cost } \\
\text { with BOP } \\
\text { (MS) }\end{array}$ & $\begin{array}{l}\text { Component } \\
\text { OC cost } \\
\text { with BOP } \\
(\mathrm{S} / \mathrm{kWe})\end{array}$ \\
\hline 6.3 & Ash handling & Coal ash, mt/day & 477.8 & 0.67 & 34.3 & 591.8 & 46.4 & 54.9 & 55.0 \\
\hline 6.4 & Stand-alone ASU & Pure $\mathrm{O}_{2}, \mathrm{mt} /$ day & 2035.0 & 0.50 & 96.1 & 5429.3 & 207.2 & 245.1 & 245.6 \\
\hline 6.5 & $\begin{array}{l}\text { Shell standard gasifier } \\
\text { \& SGcoolers }\end{array}$ & ARcoal, $\mathrm{MW}_{\text {th }} \mathrm{LHV}$ & 737.4 & 0.67 & 160.4 & 1827.8 & 345.7 & 408.9 & 409.7 \\
\hline \multirow[t]{2}{*}{6.6} & $\begin{array}{l}\text { Shell - LT heat recovery } \\
\text { \& FG saturation }\end{array}$ & ARcoal, $\mathrm{MW}_{\text {th }} \mathrm{LHV}$ & 770.9 & 0.67 & 125.7 & - & & & \\
\hline & SUBTOTAL 6 & & & & & & 741.4 & 876.9 & 878.8 \\
\hline 7 & $\mathrm{CO}_{2}$ compression & & & & & & & & \\
\hline \multirow[t]{2}{*}{7.1} & $\begin{array}{l}\mathrm{CO}_{2} \text { compression and } \\
\text { drying }\end{array}$ & Comp. power, $\mathrm{MW}_{\mathrm{e}}$ & 27.4 & 0.67 & 38.8 & 73.7 & 103.4 & 122.3 & 122.6 \\
\hline & SUBTOTAL 8 & & & & & & 103.4 & 122.3 & 122.6 \\
\hline 8 & \multicolumn{9}{|c|}{ Heat recovery steam cycle (HRSC) } \\
\hline 8.1 & $\begin{array}{l}\text { Boiler/steam generator, } \\
\text { ductwork, \& stack }\end{array}$ & Boiler duty, $\mathrm{MW}_{\mathrm{th}}$ & 355.0 & 1.00 & 52.0 & 718.2 & 98.2 & 116.2 & 116.4 \\
\hline \multirow[t]{2}{*}{8.2} & $\begin{array}{l}\text { Steam turbine (ST), } \\
\text { condenser, steam } \\
\text { piping, auxiliaries }\end{array}$ & ST gross power, $\mathrm{MW}_{\mathrm{e}}$ & 274.7 & 0.67 & 66.7 & 214.0 & 56.4 & 66.7 & 66.8 \\
\hline & SUBTOTAL 9 & & & & & & 154.6 & 182.9 & 183.3 \\
\hline 9 & \multicolumn{9}{|c|}{ Power plant BoP and auxiliaries } \\
\hline 9.1 & $\begin{array}{l}\text { BOP (feedwtr, CW, elec, } \\
\text { controls, sitework, } \\
\text { buildings) }\end{array}$ & Percentage of TPC & $15.5 \%$ & & & & & & \\
\hline \multicolumn{8}{|c|}{ Total plant cost (TCP), 2007M\$ } & 2046 & 2050 \\
\hline
\end{tabular}

\section{References}

Adams, T.A., Barton, P.I., 2010. High-efficiency power production from natural gas with carbon capture. J. Power Sources 195 (7), 1971-1983.

Agrawal, G., 2009. Advances in fuel cell blowers. In: 10th Annual SECA Workshop, Pittsburgh, PA, USA.

Bloom Energy (US). www.bloomenergy.com, Website news section (last accessed $15.04 .11)$

Bose, D., Batawi, E.E., Couse, S., Hickey, D., Mcelroy, J., 2007. Solid oxide fuel cell system with internal reformation. Patent No. WO 2008/123968.

Campanari, S., Chiesa, P., Manzolini, G., 2010. $\mathrm{CO}_{2}$ capture from combined cycles integrated with molten carbonate fuel cells. Int. J. Greenhouse Gas Control 4,

441-451.

Carbo, M.C., Boon, J., Jansen, D., van Dijk, H.A.J., Dijkstra, J.W., van den Brink, R.W., Verkooijen, A.H.M., 2009a. Steam demand reduction of water-gas shift reaction in IGCC power plants with pre-combustion $\mathrm{CO}_{2}$ capture. Int. J. Greenhouse Gas Control 3 (6), 712-719.

Carbo, C., Jansen, D., Boon, J., Dijkstra, J.W., van den Brink, R.W., Verkooijen, A.H.M. 2009b. Staged water-gas shift configuration: key to efficiency penalty reduction during pre-combustion decarbonisation in IGCC. Energy Procedia 1 (1), 661-668.

"Chemical Engineering" Magazine, Monthly. See http://www.che.com/pci/

Papadias, D.D., Ahmed, S., Kumar, R., 2012. Fuel quality issues with biogas energy an economic analysis for a stationary fuel cell system. Energy 44 (August (1))

257-277.

Discepoli, G., Cinti, G., Desideri, U., Penchini, D., Proietti, S., 2012. Carbon capture with molten carbonate fuel cells: experimental tests and fuel cell performance assessment. Int. J. Greenhouse Gas Control 9, 372-384.

DOE Report, 2006. Practical Experience Gained during the First Twenty Years of Operation of the Great Plains Gasification Plant and Implications for Future Projects.

DOE/NETL-2002/1169 Report, 2002. Process Equipment Cost Estimation: Final Report.

DOE/NETL-2010/1397 Report, 2010. Cost and Performance Baseline for Fossil Energy Plants Volume 1: Bituminous Coal and Natural Gas to Electricity.

DOE/NETL-2011/1486 Report, 2011a. Analysis of Natural Gas Fuel Cell Plant Configuration.

DOE/NETL-2011-1482 Report, 2011b. Analysis of Integrated Gasification Fuel Cell Plant Configurations.

DOE/NETL-2010/1402 Report, 2011c. Cost and Performance Baseline for Fossil Energy Plants Volume 2: Coal to Synthetic Natural Gas and Ammonia.

Electric Power Research Institute (EPRI), 1993. Technical Assessment Guide, Volume 1: Electricity Supply. Report Number TR-102276-V1R7.

EU Project ENE.FIELD. www.enefield.eu

Föger, K., 2010. BlueGen - ceramic fuel cells first product for commercial roll-out. In: Fuel Cell Seminar Presentation 2010, San Antonio, TX, USA, October

Franzoni, A., Magistri, L., Traverso, A., Massardo, A.F., 2008. Thermoeconomic analysis of pressurized hybrid SOFC systems with $\mathrm{CO}_{2}$ separation. Energy 33 (2),

311-320.

Fuel Cell Energy Inc. 2014, http://www.fuelcellenergy.com/
Gerdes, K., Grol, E., Kearins, D., Newby, R., 2009. DOE/NETL-2009/1361. In: Integrated Gasification Fuel Cell Performance and Cost Assessment.

Green, D.W., 2007. Perry's Chemical Engineers' Handbook, 8th ed. McGraw-Hill, New York, US.

Grol, E., 2009. DOE/NETL-40/080609 Report. In: Systems Analysis of an Integrated Gasification Fuel Cell Combined Cycle.

GTW, 2003. Gas Turbine World 2003 Handbook. Pequot Publishing, Fair-field, CT.

Personal communication with Haldor Topsoe.

Hassmann, K., 2001. SOFC power plants, the Siemens-Westinghouse approach. Fuel Cells 1 (1), 78-84.

IEA (International Energy Agency), 2003. Potential for Improvement in Gasification Combined Cycle Power Generation with CO2 Capture. IEA Greenhouse Gas R\&D Programme Report PH4/19: Cases A.1 and B.3.

International Energy Agency (IEA), 2012. Energy Technology Perspective 2012

Israelson, G., 2004. Results of testing various natural gas desulfurization adsorbents. J. Mater. Eng. Perform. 13 (3), 282-286.

Japanese group unveils, SOFC Ene-Farm residential cogen unit., 2012. Fuel Cells Bull.,

Kohl, A.L., Nielsen, R.B., 1997. Gas Purification, 5th ed, ISBN: 0-88415-220-0. Kreutz,

T.G., Williams, R.H., Consonni, S., Chiesa, P., 2005a. Co-production of hydrogen, electricity and $\mathrm{CO}_{2}$ from coal with commercially ready technology. Part B: economic analysis. Int. J. Hydrogen Energy 30, 769-784.

Kreutz, T.G., Chiesa, P., Williams, R.H., 2005b. Techno-Economic Analysis of Hydrogen and Electricity Production from Coal with Near Zero Pollutant and CO2 Emissions using an Inorganic Hydrogen Separation Membrane Reactor: B. System Optimization and Comparative Analysis. Internal Report. Princeton Environmental Institute, Princeton University.

Kreutz, T.G., Larson, E.D., Liu, G., Williams, R.H., 2008. Fischer-Tropsch Fuels from Coal and Biomass. In: 25th Annual International Pittsburgh Coal Conference, Pittsburgh, PA, USA.

Kuramochi, T., Turkenburg, W., Faaij, A., 2011. Competitiveness of $\mathrm{CO}_{2}$ capture from an industrial solid oxide fuel cell combined heat and power system in the early stage of market introduction. Fuel 90 (3), 958-973.

Lanzini, A., (Ph.D. thesis) 2011. Study of Solid Oxides Fuel Cell Systems Running on Poly-Fuel Mixtures. Department of Energy, Politecnico di Torino, Torino, Italy.

Lanzini, A., Leone, P., 2010. Experimental investigation of direct internal reforming of biogas in solid oxide fuel cells". Int. J. Hydrogen Energy 35 (6), 2463-2476.

Lanzini, A., Santarelli, M., Orsello, G., 2010. Residential solid oxide fuel cell generator fuelled by ethanol: cell, stack and system modelling with a preliminary experiment. Fuel Cells 10 (4), 654-675.

Lanzini, A., Kreutz, T.G., Martelli, E., Santarelli, M., 2012. Techno-economic analysis of integrated gasification fuel cell power plants capturing $\mathrm{CO}_{2}$. In: Proceeding of ASME Turbo Expo 2012, pp. 337-347.

Larson, E.D., Williams, R.H., Kreutz, T.G., Liu, G., Lanzini, A., Hannula, I., 2012 Energy, Environmental, and Economic Analyses of Design Concepts for the CoProduction of Fuels and Chemicals with Electricity via Co-Gasification of Coal and Biomass. Princeton University's Report under DOE Agreement DE-FE0005373.

Li, M., Rao, A.D., Brouwer, J., Samuelsen, G.S., 2010. Design of highly efficient coalbased integrated gasification fuel cell power plants. J. Power Sources 195 (17) 5707-5718. 
Linnhoff, B., Hindmarsh, E., 1983. The pinch design method for heat exchanger networks. Chem. Eng. Sci. 38 (5), 745-763.

Liu, M., Lanzini, A., Halliop, W., Cobas, V.R.M., Verkooijen, A.H.M., Aravind, P.V., 2013. Anode recirculation behavior of a solid oxide fuel cell system: a safety analysis and a performance optimization. Int. J. Hydrogen Energy 38 (6), 2868-2883.

Lundberg, W.L., Israelson, G.A., Holmes, R.A., Zafred, P.R., King, J.E., Kothmann, R.E., 2000. Pressurized Solid Oxide Fuel Cell/Gas Turbine Power System. Siemens Westinghouse, Pittsburg, US

Martelli, E., (Ph.D. thesis) 2010. Numerical Optimization of Heat Recovery Steam Cycles for Highly Integrated Energy Systems. Department of Energy, Politecnico di Milano, Milano, Italy.

Martelli, E., Amaldi, E., Consonni, S., 2011a. Numerical optimization of heat recovery steam cycles: mathematical model, two-stage algorithm and applications. Comput. Chem. Eng. 35 (12), 2799-2823.

Martelli, E., Kreutz, T.G., Carbo, M., Consonni, S., Jansen, D., 2011b. Shell coal IGCCS with carbon capture: conventional gas quench vs. innovative configurations.

Appl. Energy 88 (11), 3978-3989.

Massardo, A., Lubelli, F., 2000. Internal reforming solid oxide fuel cell-gas turbine combined cycles (IRSOFC-GT): Part A - cell model and cycle thermodynamic analysis. J. Eng. Gas Turbines Power 122, 22-35.

McLarty, D., Brouwer, J., Samuelsen, S., 2013. A spatially resolved physical model for transient system analysis of high temperature fuel cells. Int. J. Hydrogen 38 (19), 7935-7946.

Milewski, J., Świrski, K., Santarelli, M., Leone, P., 2011. Advanced Methods of Solid Oxide Fuel Cell Modeling, 1st ed. Springer, London, UK.

Park, S.K., Kim, T.S., Sohn, J.L., Lee, Y.D., 2011. An integrated power generation system combining solid oxide fuel cell and oxy-fuel combustion for high performance and $\mathrm{CO}_{2}$ capture. Appl. Energy 88 (4), 1187-1196.

Pedersen, K., Skov, A., Rostrup-Nielsen, J.R., 1980. Catalytic aspects of high temperature methanation. ACS Fuel Chem. Div. Preprints 25 (2), 89-100.

Penner, S.S., 1987. Coal Gasification: Direct Applications and Syntheses of

Chemicals and Fuels. University of California, San Diego.

Rao, A.D., 1991. Reactor expander topping cycle. U.S. Patent No. 4,999,993.

Ravagni, A., 2011. Key-Note Presentation at the "International Panel on Hydrogen and Fuel Cell Economy (IPHE)" roundtable, Berlin, November.

Romano, M.C., Spallina, V., Campanari, S., 2011. Integrating IT-SOFC and gasification combined cycle with methanation reactor and hydrogen firing for near zero-

emission power generation from coal. Energy Procedia 4, 1168-1175. Rostrup-

Nielsen, J.R., Pedersen, K., Sehested, J., 2007. High temperature methanation. Appl. Catal. A: Gen. 330, 134-138.
Seidler, S., Henke, M., Kallo, J., Bessler, W.G., Maier, U., Friedrich, K.A., 2011. Pressurized solid oxide fuel cells: experimental studies and modeling. J. Power Sources 196, 7195-7202.

Singhal, S.C., 1999. Progress in tubular solid oxide fuel cell technology. In: SOFC-VI Symposium, ECS Proceedings Volume.

Ghezel-Ayagh, H., 2009. Solid Oxide Fuel Cell Program at Fuel Cell Energy Inc. In 10th Annual SECA Workshop, Pittsburgh, PA.

Spallina, V., Romano, M.C., Campanari, S., Lozza, G., 2011a. Thermodynamic analysis and optimization of IT-SOFC-based integrated coal gasification fuel. J. Fuel Cell Sci. Technol. 8 (4), 0410021-04100211.

Spallina, V., Romano, M.C., Campanari, S., Lozza, G., 2011b. A SOFC-based integrated gasification fuel cell cycle with $\mathrm{CO}_{2}$ capture. J. Eng. Gas Turbines Power 133 (7), 0410061-04100610.

Thijssen, J.H.J.S., 2007. The Impact of Scale-Up and Production Volume on SOFC Manufacturing Cost. National Energy Technology Laboratory.

Thijssen, J.H., Thijssen, J., 2009. Stack Operating Strategies for Central Station SOFC. In: Presentation at Fuel Cell Seminar 2009, Palm Springs, California, USA November 16-19.

Thydén, K., (Ph.D. thesis) 2008. Microstructural Degradation of Ni-YSZ Anodes for Solid Oxide Fuel Cells. Risø DTU, 112 p. ISBN: 978-87-550-3625-3.

Trasino, F., Bozzolo, M., Magistri, L., Massardo, A.F., 2011. Modeling and performance analysis of the rolls-royce fuel cell systems limited: $1 \mathrm{MW}$ plant. J. Eng. Gas Turb.

Power-Trans. ASME 133 (2), 0217011-02170111.

Traverso, A., Magistri, L., Massardo, A.F., 2010. Turbomachinery for the air management and energy recovery in fuel cell gas turbine hybrid systems. Energy 35 , 764-777.

Turton, R., et al., 2003. Analysis, Synthesis and Design of Chemical Processes, 3rd ed. Prentice Hall, New York, US

Twigg, M., 1996. Catalyst Handbook, 2nd ed., pp. 374-375.

Udengaard, N.R., Olsen, A., Wix-Nielsen, C., 2006. High temperature methanation process - revisited. In: 23rd Annual International Pittsburgh Coal Conference September.

2006. Practical Experience Gained During the First Twenty Years of Operation of the Great Plains Gasification Plant and Implications for Future Projects. US DOE Report, Available at http://www.fossil.energy.gov/programs/ powersystems/publications/Brochures/dg knowledge gained.pdf

Vora, S., 2011. Overview of DOE SECA program. In: 12th Annual SECA Workshop, Pittsburgh, PA, July 26-28.

Yokokawa, H., 2013. Report of five-year NEDO project on durability/reliability of SOFC stacks. ECS Trans. 57 (1), 299-308. 